\title{
The impact of damming on riverine fluxes to the ocean: a case study from Eastern Iceland.
}

Eydis Salome Eiriksdottir ${ }^{1,2}$, Eric H. Oelkers ${ }^{1,3,4}$, Jorunn Hardardottir ${ }^{5}$ and Sigurdur Reynir Gislason ${ }^{1}$.

${ }^{1}$ Institute of Earth Sciences, Sturlugata 7, 101 Reykjavik, Iceland

${ }^{2}$ Marine and Freshwater Research Institute, Árleynir 22, 112 Reykjavik, Iceland,

eydis.salome.eiriksdottir@hafogvatn.is

${ }^{3}$ GET, CNRS/URM 5563-Université Paul Sabatier, 14 rue Edouard Belin, 31400, Toulouse, France

${ }^{4}$ Earth Science, University College London, Gower Street WC1E 6BT, United Kingdom

5/celandic Meteorological Office, Bústadavegur 7-9, 108 Reykjavik, Iceland

Keywords: Glacial river damming, Kárahnjúkavirkjun, Hálslón reservoir, anthropogenic effects, dissolved element fluxes, suspended material fluxes, basaltic river catchments.

\begin{abstract}
Anthropogenic water management has extensively altered the worlds' river systems through impoundments and channel diversions to meet the human's need for water, energy and transportation. To illuminate the effect of such activities on the environment, this study describes the impact of the installation of the Kárahnjúkar Dam in Eastern Iceland on the transport of riverine dissolved- and particulate material to the ocean by the Jökulsá á Dal and the Lagarfljót rivers. This dam, completed in 2007, collects water into the $2.2 \mathrm{~km}^{3}$ Hálslón reservoir and diverts water from the glacial Jökulsá á Dal river into the partially glaciated Lagarfljót lagoon via a headrace tunnel. The impact of the damming was evaluated by sampling
\end{abstract}


water from both the Jökulsá á Dal and the Lagarfljót rivers over a 15 year period spanning from 1998 to 2013.

The annual flux of most dissolved elements increased substantially due to the damming. The fluxes of dissolved $\mathrm{Zn}, \mathrm{Al}, \mathrm{Co}, \mathrm{Ti}$ and $\mathrm{Fe}$ increased most by damming; these fluxes increased by 46 to $391 \%$. These differences can be attributed to changed saturation states of common secondary minerals in the Jökulsá á Dal due to reduced discharge, increased residence time and dissolution of suspended material, and, to a lesser degree, reduced photosynthesis due to less transparency in the Lagarfljót lagoon. The removal of particulate material and thus decreasing adsorption potential in the Jökulsá á Dal is the likely reason for the Fe flux increase. In contrast, approximately $85 \%$ of the original riverine transported mass of particulate material is trapped by the dam; that which passes tends to be relatively fine grained, increasing the average specific surface area of that which continues to flow towards the ocean. Consequently, the particulate geometric surface area flux is decreased by only $50 \%$ reduction due to the damming.

The blooming of silica diatoms during the spring consumes dissolved silica from the coastal waters until it becomes depleted; making the riverine spring dissolved silica flux an important source of this nutrient. Despite extensive riverine flux changes due to the Kárahnjúkar dam construction, the total spring dissolved silica flux increased, and thus so too the potential for a silica diatom spring bloom in the coastal waters. This is likely because the spring flux is dominated by snow melting downstream of the dam.

\section{INTRODUCTION}


Riverine transport from the continents to the oceans plays a major role in the global cycling of the elements including providing essential nutrients to the coastal oceans to sustain marine primary productivity (e.g. Falkowski et al., 1998; Jickells, 1998; Holland, 2005). The world's rivers transport material both in dissolved and particulate form. Global dissolved riverine transport has been estimated to be approximately $2 \mathrm{Gt} / \mathrm{yr}$ (Gaillardet et al., 1999) and the global particulate riverine transport of rivers, including both bedload and suspended particles is estimated to be 16-30 Gt/yr, excluding the effects of dams (Milliman and Syvitski, 1992; Syvitski et al., 2005; Walling, 2006).

A growing population requires a stable supply of water. Dams play a major role in addressing these needs. Damming increases the retention time of water and suspended sediments on land and can cause a major change of the hydrological, physical, chemical and biological properties of the water. It can cause water shortages or changes in biological activity downstream from the dam due to anoxia, sedimentation, and changed nutrient state due to nutrient uptake and/or increased flux of nutrients from the reservoirs (Friedl and Wüest, 2002). Vörösmarty et al. (2003) estimated that $40 \%$ of the global river discharge was intercepted by 633 of the worlds' largest surface water reservoirs $\left(\geq 0.5 \mathrm{~km}^{3}\right.$ maximum storage capacity). Dams of different sizes, intercepting tributaries and/or main channels of $65 \%$ of the world's major rivers, have been constructed since the late $19^{\text {th }}$ century, capable of retaining $15 \%$ of the total annual global river runoff (Nilsson et al. 2005). According to Syvitski et al. (2005) the global particulate flux to the oceans has decreased by $25 \%$ due to dam constructions. This decrease is more dramatic on a local or regional scale; the sediment load of some of the world's largest rivers has been reduced by $64-100 \%$ due to dam construction (Vörösmarty et al., 2003; Walling and Fang, 2003; Walling 2006). For example, the particulate mass flux of large Chinese rivers 
has decreased by $80 \%$ over the past 50 years due to dam construction (Wang et al., 2008; 2010; Gupta et al. 2012).

Changes in particulate mass fluxes to the ocean may have a substantial effect on marine chemistry, as numerous studies have shown that there is a substantial release of soluble and insoluble elements from riverine particulates to seawater over a timescale of minutes, days and months (Aller, 1998; Elrod et al., 2004; Stefansdottir and Gislason, 2005; Noble et al., 2008; Peucker-Ehrenbrink et al., 2010; Jeandel et al., 2011; Jones et al., 2012a; 2012b; Singh et al., 2012; Pearce et al., 2013; Jones et al., 2014; Jeandel and Oelkers, 2015; Morin et al., 2015). As the global mass of particulates transported to the oceans by rivers exceeds that transported in dissolved form by at least an order of magnitude, particulate fluxes are a major contributor of elements to the oceans, especially for insoluble elements (Oelkers et al., 2012, Eiriksdottir et al., 2015) of which many are essential micronutrients (Martin et al., 1991; Morel et al., 2003; Ruttenberg, 2003). Jeandel and Oelkers (2015) summarized numerous studies reporting significant particulate-seawater interaction (Arsouze et al., 2009; Allègre et al., 2010; Jones et al., 2012a; 2012b; Tréguer and de la Rocha, 2013) and concluded that particle dissolution in seawater may provide a strong link between continental weathering and climate through the inorganic and organic pathway of $\mathrm{CO}_{2}$ removal from the atmosphere.

Damming also changes the seasonality of suspended- and dissolved material fluxes (Friedl and Wüest, 2002). This can be particularly significant, as the timing of riverine fluxes can be an important source of essential nutrients for the spring bloom of primary producers downstream from the dam and in the coastal waters. Dissolved nutrients accumulated in reservoirs can be consumed by biota or adsorbed on particles. Such processes can lead to the reduction of nutrient fluxes downstream of the dam and to the coastal waters. Phosphorus, an essential macronutrient for primary productivity, has been found to be especially sensitive to 
damming since it is mostly present in rivers within particles or adsorbed to the surfaces of suspended sediments including iron(oxyhydr)oxide (Ruttenberg, 2003; Raiswell and Canfield, 2012).

The Kárahnjúkar dam, the largest dam of its type in Europe, was built on the Jökulsá á Dal glacial river catchment in Eastern Iceland during 2003-2007 (Fig. 1). Its purpose was to create a reservoir for a $690 \mathrm{MW}$ hydropower plant. The construction was completed and power production began by the end of 2007. From 1970 to 1999 the Jökulsá á Dal carried an average 5.8 million tonnes of suspended sediment per year (Pálsson et al., 2000) and was among the Icelandic rivers with the highest sediment load (Tómasson, 1990). The Kárahnjúkar dam diverts water through a headrace tunnel from the upper reaches of the Jökulsá á Dal catchment into the neighbouring Lagarfljót catchment (Fig. 1). The average discharge of the Lagarfljót after dam construction doubled and subsequently the water residence time in the Lagarfljót lagoon is half of what it was previously, six months instead of one year (Tómasson and Hardardóttir, 2001).

In an attempt to quantify the effect of the dam construction on river water chemistry and dissolved and particulate fluxes to the ocean, these rivers were monitored for five years prior to dam construction (1998-2003) and again for five years after the completion of the dam (20082013). The purpose of this paper is to report the changes in fluxes of dissolved- and suspended constituents, arising due to dam construction and to assess the environmental effect of these changes.

\subsection{Study area}

This study focusses on environmental changes caused by the construction of the Kárahnjúkar dam on the Jökulsá á Dal and Lagarfljót catchments (Fig. 1). These river catchments are partially glaciated, with glaciers covering $43 \%$ of the Jökulsá á Dal catchment 
and 6\% of the Lagarfljót catchment (Kardjilov 2008). Heath, grassland and cultivated land make up 23 and $21 \%$ of the total catchment area, respectively, 11 and $10 \%$ is wetland and 24 and $21 \%$ is sparsely vegetated (Kardjilov, 2008). Five farms are located above the power station. The population is scarce in the area, and the reservoir area has never been inhabited. The population density in the river catchments was 0.45 person $\mathrm{km}^{-2}$ before damming and is 0.57 person $\mathrm{km}^{-2}$ after damming (Statistics Iceland, 2016).

This study takes advantage of continuous discharge measurements and the concentrations of the dissolved and suspended load of these rivers determined on samples collected before and after dam construction. Samples were collected eight to ten times per year from 1998 to 2003 (before the damming) and again eight times per year from 2008 to 2013 (after damming) during all seasons from the Jökulsá á Dal at Hjardarhagi and the Lagarfljót at Lagarfoss. Samples were also collected from the pristine direct runoff Fellsá, river, located near-by, and used as a control, to account for natural fluctuations and possible deviations due to sampling and analytical methods during this study.

The climate in the area differed somewhat over the two study periods. During the predamming study period, the catchments experienced warming where the average annual temperature went from 2.3 to $4.7^{\circ} \mathrm{C}$. The climate was more stable after damming. The average annual air temperature and rainfall in the area was $3.52{ }^{\circ} \mathrm{C}$ and $1304 \mathrm{~mm}$ during $1998-2003$ and $3.72{ }^{\circ} \mathrm{C}$ and $1177 \mathrm{~mm}$ during 2008-2013 (The Icelandic Meteorological Office, 2016). The effect of climate change on chemical weathering rates and riverine fluxes using data from the pristine river catchments collected before damming, was reported by Gislason et al., (2006) and Eiriksdottir et al. (2015). 
The Jökulsá á Dal is a glacial river fed by the Brúarárjökull glacier, at the NE part of the Vatnajökull ice cap. The bedrock consists of young, glassy basalts (Eiriksdottir et al., 2008; Gislason et al., 2009), sparsely vegetated but with some heath/grassland and some wetland areas (Kardjilov et al., 2006; Kardjilov 2008). The volcanic rift zone in Iceland affects the spatial distribution of dissolved riverine constituents; higher weathering rates have been observed within the rift zone than on the older geological formations (Oskarsdottir et al., 2011). The Jökulsá á Dal river is $138 \mathrm{~km}$ long from the glacier to the coast and samples were collected at Hjardarhagi, $\sim 50 \mathrm{~km}$ from the coast. The Kárahnjúkar dam is $193 \mathrm{~m}$ tall and $799 \mathrm{~m}$ long. It created an up to $63 \mathrm{~km}^{2}$ reservoir, the Hálslón, with a reservoir capacity of 2200 gigaliters (2.2 $\mathrm{km}^{3}$ ) of water that reaches to within $25 \mathrm{~km}$ of the Brúarárjökull glacier (Gunnarsson, 2014). From the reservoir, the water is diverted through a tunnel creating a $600 \mathrm{~m}$ vertical drop and through a power plant. The water is then released into the Jökulsá í Fljótsdal and eventually into the Lagarfljót lagoon. The average discharge through the tunnel is $110 \mathrm{~m}^{3} / \mathrm{s}$ (Landsvirkjun, 2009).

\subsection{Methods}

The collection and analysis of samples was previously described by Gislason et al. (2009) and Eiriksdottir et al. $(2013 ; 2015)$. A total of 259 water samples were collected from the three studied rivers; the Jökulsá á Dal at Hjardarhagi, the Lagarfljót at Lagarfoss, and the Fellsá, 132 samples prior to and 127 samples after dam construction. Samples were collected throughout the year to account for seasonal changes on the chemical compositions of the rivers. All fluid samples were filtered on site through $0.2 \mu \mathrm{m}$ Millipore cellulose acetate filters using a peristaltic pump, silicone tubing, and a $142 \mathrm{~mm}$ Sartorius filter holder. Water samples collected for major cations and trace element analyses were acidified with suprapure $\mathrm{HNO}_{3}$. Total suspended inorganic and organic matter (SIM and POC/PON) were sampled from the main channel of the 
rivers using either a DH48 or a S49 sampler (Guy and Norman, 1970). The S49 sampler was used in the Jökulsá á Dal but the DH48 sampler was used in the Lagarfljót and Fellsá rivers.

Water samples were collected and analysed in distinct ways for distinct chemical analyses. Samples collected for $\mathrm{pH}$ and alkalinity measurement were collected in amber glass bottles and filled completely from the bottom to avoid air in the samples. The samples for $\mathrm{pH}$ were kept cold until it was measured using a Cole-Palmer combined glass electrode together with an Orion pH meter. The electrodes were calibrated using 4.01 and 7.00 NBS standards prior to all measurements. The uncertainty of the $\mathrm{pH}$ measurements is estimated to be \pm 0.02 . Samples for determining the composition of major $\left(\mathrm{Ca}, \mathrm{K}, \mathrm{Mg}, \mathrm{Na}, \mathrm{SiO}_{2}, \mathrm{~S}\right.$-total) and trace cations (Fe, $\mathrm{Al}$, As, B, Ba, Cd, Co, Cr, Cu, Hg, Mn, Mo, Ni, P-total, Pb, Sr, Ti, V, Zn) was measured using either an Optima 4300 DV Series Inductively Coupled Plasma Atomic Emission Spectroscopy (ICP-AES) or an Element 1 Inductively Coupled Plasma Sector Field Mass Spectroscopy (ICPSFMS) located at ALS Scandinavia, Luleå in Sweden. These analyses were performed according to EPA-method USP 200.7(mod) for ICP-AES and EPA-method 200.8(mod) for ICP-SFMS; the National Research Council of Canada SLRS-4 river water reference material was used for external blind quality tests. The uncertainties of these measurements are less than $5 \%$. Samples for alkalinity measurements were kept cold until alkalinity was determined by Gran titration (c.f. Stumm and Morgan, 1996). Concentrations of $\mathrm{Cl}, \mathrm{SO}_{4}$, and $\mathrm{F}$ were determined using a Dionex anion chromatograph. The concentration of the nutrients $\mathrm{PO}_{4}, \mathrm{NO}_{2}$, $\mathrm{NO}_{3}$, and $\mathrm{NH}_{4}$ were determined using segmented flow analysis on an Alpkem colorimetric system with an uncertainty of $\pm 5 \%$. Total nitrogen was measured by digesting the water samples for 2 hours in a Metrohm 705 UV digestor after adding $\mathrm{H}_{2} \mathrm{O}_{2}$ to the samples, before analysing the samples for $\mathrm{NO}_{2}$ and $\mathrm{NO}_{3}$. 
To eliminate the effects of sea spray input on calculated fluxes, fluid concentrations were corrected assuming that all the dissolved $\mathrm{Cl}$ present in the water samples originated from rainwater and using the element/Cl ratio of Icelandic rainwater (Gislason et al., 1996). The total dissolved inorganic carbon (DIC) was calculated from the measured alkalinity, $\mathrm{pH}$, temperature, total dissolved silica, and discharge at the time of sampling. The average charge imbalance of the samples was $3 \%$. Modelling of the saturation state of the river waters with respect of different primary- and secondary phases was carried out using PhreeqC together with the thermodynamic database reported by Gysi and Stefánsson (2011).

River discharge was measured continuously during the study using a digital pressure sensor and the measured relationship between water level and discharge in each river (The Icelandic Meteorological Office, 2014). Daily average discharge was calculated from these continuous discharge measurements. The concentration of the suspended inorganic particulate matter (SIM) and the particulate size distribution was measured using sieves and a sediment settling scale by the Icelandic Meteorological Office. The organic fraction of the suspended sediment was removed prior to analysis by boiling the sample in hydrogen peroxide (Pálsson and Vigfússon, 1996). The geometric surface area of the suspended inorganic matter was calculated from the average particle diameter and the grain density, assuming that the grains were a perfect cubic shape (Wolff-Boenisch et al., 2004). The chemical composition of the SIM samples collected from 1998 to 2003 was measured as described by Eiriksdóttir et al. (2008). Analysis of particulate carbon and nitrogen was performed on glass fibre filters (Whatman GF/F $0.7 \mu \mathrm{m}$ pre-combusted for $4 \mathrm{~h}$ at $450{ }^{\circ} \mathrm{C}$ ) with a Carlo Erba model 1108 high temperature combustion elemental analyser, using standard procedures and a combustion temperature of $1030{ }^{\circ} \mathrm{C}$. Acetanilide was used for standardisation, and results were corrected for blank filter carbon content. The propagation of variance of the element flux calculations were estimated to be $11 \%$, 
given that the discharge has a 5\% uncertainty and analytical error on dissolved and suspended matter is $10 \%$.

Riverine element fluxes of dissolved and suspended matter were calculated by multiplying the concentration of suspended matter and chemical concentration of each element by the corresponding discharge at the time of sampling. The relationship between the river discharge at the time of sampling and the instantaneous fluxes of SIM and dissolved elements was fit to power functions (c.f. Eiriksdottir et al., 2015). These functions were used together with the daily average discharge of each river, to calculate the daily average flux of the constituent of interest. These average fluxes were summed over each year to yield the average annual flux of each constituent.

\section{RESULTS}

The concentrations of dissolved elements and suspended material, $\mathrm{pH}$ of the river water, instantaneous discharge, and water- and air temperature before the damming occurred as well as the effect of climate change on riverine fluxes of dissolved and suspended material was reported by Eiriksdottir et al. (2015). Comparable data from after the damming is presented in the electronic supplement (Table A2 in the electronic annex).

Due to damming, the annual discharge of the Jökulsá á Dal at Hjardarhagi was $64 \%$ lower during 2008-2013 than during 1998-2003. There is a direct relationship between river discharge and the concentration of suspended inorganic matter (SIM) (Tómasson, 1990; Gislason et al., 2006; 2009; Eiriksdottir et al., 2015) but there is an inverse relationship between river discharge and the concentration of most dissolved elements in the river water (Eiriksdottir et al., 2015). Therefore, changes in river discharge have direct effects on the riverine fluxes of 
dissolved elements, of which many play an important role in nutrient supply to the coastal waters (Falkowski, 2003; Eiriksdottir et al., 2015).

Figure 2 shows the variation of SIM and selected dissolved element fluxes as a function of discharge in (a) the Jökulsá á Dal at Hjardarhagi and (b) the Lagarfljót at Lagarfoss. The datasets collected before and after dam construction show that the discharge dependence of the fluxes of some elements has changed dramatically, while the impact on other elements is limited. Equations describing element fluxes as a function of discharge and their coefficients of determination are provided in Table A1 in the electronic supplement and have been used together with average daily discharge (The Icelandic Meteorological Office, 2014) to calculate the daily- and annual fluxes of the elements (see Eiriksdottir et al., 2015). After the Hálslón reservoir filled in late summer, it overflows into the Jökulsá á Dal river channel and changes dramatically the river discharge and the concentration of suspended and dissolved material of this river downstream. To calculate the element fluxes in the Jökulsá á Dal after damming it is therefore necessary to use two distinct flux-discharge equations for many elements, one with and one without water overflowing from the reservoir into the river channel (Fig. 2; Table A1). To ensure consistency, one form of this fit equation was used for all flux calculations, although in a few cases the resulting fit between the discharge and the fluxes is less strong.

The annual average dissolved element fluxes before and after dam construction, generated by integrating the average daily element fluxes of each river over each year are presented in Table 1. Since the two rivers, the Jökulsá á Dal and Lagarfljót, have the same outlet at the coast, their combined annual fluxes are also presented in Table 1. A positive relative change in this table represents an increased annual flux due to damming, while a negative number represents a decreased annual flux. 
The discharge dependence of the SIM flux in the Jökulsá á Dal (Fig. 2a) decreased greatly after the dam construction. The SIM flux in the neighbouring Lagarfljót river (Fig. 2b) increased as the diverted water from the dammed glacial Jökulsá á Dal, which is now released into the Lagarfljót, has much higher SIM load than the natural Lagarfljót river, even though most of the SIM entering the Hálslón reservoir is retained by the dam. In contrast, the dam construction has limited impact on the discharge dependence of the dissolved fluxes of many elements including $\mathrm{SiO}_{2}, \mathrm{Na}, \mathrm{K}, \mathrm{Ca}, \mathrm{DIC}, \mathrm{F}, \mathrm{NO}_{2}, \mathrm{~N}$-total, $\mathrm{B}, \mathrm{Cr}, \mathrm{Pb}$ (see Table A1 in the electronic appendix). Interestingly, Fe fluxes increased far more than discharge after dam construction (Fig. 2).

The average daily discharge and flux of SIM and selected dissolved elements in the Jökulsá á Dal before and after the dam construction are presented in Fig. 3. The presented averages were calculated from the measured daily average discharge and the calculated fluxes for each day of the two study periods, 1998-2003 and 2008-2013; results are reported as two separate datasets for the two periods. Several observations are apparent on this figure. First, the Jökulsá á Dal runoff decreased due to the water diversions from $1.44 \mathrm{~m} / \mathrm{yr}$ before damming to $0.51 \mathrm{~m} / \mathrm{yr}$ after damming (Table 1). The annual discharge distribution also changed. Before damming, discharge increased 30 fold from the lowest winter discharge to the highest summer discharge. After damming, there are two discharge peaks, one during snowmelt in the spring and another when the reservoir overflows. The spring peak is similar before and after the damming. The post damming late summer discharge peak, due to the overflowing of the Hálslón reservoir (Fig. 1), is only half as high as the pre-damming summer discharge peak and lasts for a shorter time period. Second, fluxes of SIM and various dissolved elements are greatly affected by changes in annual runoff. The SIM flux decreased dramatically due to damming since most of the glacially derived sediment now accumulates in the Hálslón reservoir (Fig. 1). Subsequently, the 
annual geometric surface area $\left(\mathrm{A}_{\mathrm{geo}}\right)$ of suspended particles carried by the Jökulsá á Dal has decreased to an average $1.21 \times 10^{5} \mathrm{~km}^{2} / \mathrm{yr}$ compared to an average $1.8 \times 10^{6} \mathrm{~km}^{2} / \mathrm{yr}$ prior to the damming, or by 93\% (Table 1). Third, most dissolved element fluxes change proportionally with the discharge (Fig. 3) with some notable exceptions. The fluxes of some elements, particularly the nutrients phosphorus and nitrogen, decreased more than can be explained by the discharge decrease, while the fluxes of Fe and dissolved organic carbon (DOC) increased more relative to discharge. The iron increase after the damming is of special interest since iron is often a limiting nutrient in the ocean. The annual iron flux increased by $391 \%$ after damming, mostly due to a large flux peak during the spring melt (Fig. 3).

Corresponding, Fig. 4 shows the average daily discharge and SIM flux and selected dissolved elements in the Lagarfljót at Lagarfoss before and after the dam construction. Since the impounded water in the Hálslón reservoir is diverted from the Jökulsá á Dal to the Lagarfljót catchment through the headrace tunnel (Fig. 1), discharge in the Lagarfljót has roughly doubled due to damming (Table 1). The chemical composition of the water diverted from the Jökulsá á Dal differs from that of the Lagarfljót. Due to increased discharge, the SIM and most element fluxes in the Lagarfljót have increased due to damming. The annual SIM flux in the Lagarfljót increased sevenfold due to damming. This large increase stems from the input of Jökulsá á Dal water, which is loaded with fine-grained suspended sediments. As a consequence, the annual geometric surface area $\left(\mathrm{A}_{\mathrm{geo}}\right)$ flux of the suspended particles in the Lagarfljót increased from an average $6.7 \times 10^{4} \mathrm{~km}^{2} / \mathrm{yr}$ prior to damming to an average $8.6 \times 10^{5} \mathrm{~km}^{2} / \mathrm{yr}$ post damming, which is a 12 fold increase. In general, the annual dissolved fluxes of most major elements, including Si and DIC increased proportionally to discharge, whereas the dissolved fluxes of many trace elements, e.g. $\mathrm{Fe}, \mathrm{Al}$, and $\mathrm{Ti}$, increased by more than can be explained by the discharge increase. The fluxes of $\mathrm{Sr}, \mathrm{Mg}, \mathrm{Cl}$ and $\mathrm{S}$-total did not increase to the same degree as 
discharge (Table 1). The annual fluxes of dissolved Fe and $\mathrm{P}$, which are essential nutrients, increased in the Lagarfljót far more than discharge due to damming.

The Jökulsá á Dal and Lagarfljót have the same coastal outlet at Héraðsflói (Fig. 1) and the chemistry of both have been altered by dam construction. As such, the overall effect of the damming on marine chemistry is likely related to the sum of the changes occurring in these two rivers. The sum of the chemical fluxes of these two rivers before and after the damming is shown in Fig. 5 and in Table 1. Several observations are apparent in Fig. 5. First, although the annual average discharge and fluxes of the major dissolved elements including $\mathrm{SiO}_{2}$ and DIC have not greatly changed (Table 1), the distribution of these fluxes over the year has changed. Second, in contrast to the major element dissolved fluxes, the fluxes of dissolved $\mathrm{Ti}$ and $\mathrm{Fe}$ increased by a factor of 2.5 and 4 , respectively. Third, the combined average annual SIM flux decreased by a factor of 7 due to damming, from $5.86 \times 10^{6}$ to $8.6 \times 10^{5}$ tonnes/yr. As a consequence, the combined annual surface area flux of the combined rivers decreased, but not by as much as the mass flux of suspended particles since geometric surface area increases exponentially with decreasing grainsize. The post-dam annual $\mathrm{A}_{\text {geo }}$ flux is approximately half of the pre-dam flux, decreasing from $1.9 \times 10^{6} \mathrm{~km}^{2} / \mathrm{yr}$ to $0.98 \times 10^{6} \mathrm{~km}^{2} / \mathrm{yr}$ (Table 1). Plots similar to Figs. 3-5, showing the average seasonal fluxes of all measured elements in the Jökulsá á Dal and Lagarfljót, as well as the combined element fluxes of these rivers are provided in Figs. A1-A3 in the Electronic Annex.

Annual fluxes of suspended and dissolved elements in the Jökulsá á Dal and Lagarfljót have been calculated before and after damming by summing the daily element fluxes over each year. The resulting average annual fluxes are presented, together with annual runoff, in Table 1. Negative and positive numbers in Table 1 indicate fluxes that have decreased and increased, respectively, due to damming. It can be seen in Table 1 that the dissolved fluxes of all elements 
except Fe, Ti, and Sr decreased in the Jökulsá á Dal, but all except Sr increased in the Lagarfljót after damming. The relative changes in these fluxes are summarized in Fig. 6. The relative changes were calculated by dividing the average annual runoff, SIM- and element fluxes after damming by those before damming. The upper broken line in Fig. 6 represents the average annual runoff change in the Lagarfljót and the lower dotted line represents the average annual runoff change in the Jökulsá á Dal. Riverine fluxes are controlled by the runoff and concentration of riverine elements. The broken lines in Fig. 6, expressing the relative annual runoff change after damming, help identify the origin of the flux changes. Element flux changes which are equal to the discharge changes (lines on Fig. 6) are controlled by discharge while SIM- and element flux changes which are higher or lower than the discharge changes are influenced by SIM and element concentration changes. The flux changes which are higher than the discharge lines on Fig. 6 are due to a concentration increase and those which are lower are due a concentration decrease (Fig. 6).

The overall effect of damming on the average annual flux of suspended- and dissolved elements of the Jökulsá á Dal and the Lagarfljót, is presented in Fig. 7 (and Table 1). Negative and positive numbers refer to fluxes that have decreased and increased, respectively, due to damming. The average combined runoff of the Jökulsá á Dal and Lagarfljót increased by 11\%, from 1998-2003 to 2008-2013 (broken line on Fig. 7), increasing the fluxes of some elements that are controlled solely by discharge. Most of the fluxes of dissolved constituents increased except the fluxes of $\mathrm{F}, \mathrm{PO}_{4}, \mathrm{NO}_{2}$, total $\mathrm{N}$ and $\mathrm{Sr}$, which decreased by $2-32 \%$. Fluxes of other dissolved elements increased by $8-53 \%$, except dissolved fluxes of Fe, which increased from 58 to 286 tonnes per year, and of Ti which increased from 4.75 to 16.7 tonnes per year, or 391 and $251 \%$, respectively (Table 1). The Fe flux increased in both the Lagarfljót and the Jökulsá á Dal, due to increased runoff in the Lagarfljót and due to increased Fe concentration in the 
Jökulsá á Dal. The average concentration of Ti in the Lagarfljót is now 10 times higher than before damming. The average annual SIM flux, however, decreased dramatically from 5.8 million tonnes/yr to 860 thousand tonnes/yr (Table 1), or by $85 \%$, due to accumulation of sediments in the Hálslón reservoir.

\section{DISCUSSION}

\subsection{Particulate dissolution and nutrient supply to the coastal ocean}

The annual suspended particle flux decreased dramatically due to damming (Figs. 5, 7 and 8). Until recently, these particulates were assumed to be inert in seawater due to slow dissolution rates and high burial rates. However, recent studies have shown that particulateseawater interaction is significant and can dominate the input to the oceans of numerous trace elements and nutrients (e.g. Jeandel et al., 2011; Jones et al., 2012a, 2012b; Pearce et al., 2013; Jones et al., 2014).

The results summarized above show that 5 million tonnes of fine grained suspended sediments are retained in the Hálslón reservoir and the Lagarfljót lagoon annually (SIM in Table 1). This mass corresponds to $85 \%$ of the combined SIM flux of the Jökulsá á Dal and Lagarfljót before damming. Most of the particulates retained by the Hálslón reservoir consist of relatively coarse grained suspended particles, 60 to $200 \mu \mathrm{m}$ in diameter, while the finer material passes through the power turbines into the Lagarfljót. After damming, the most common grains in the Lagarfljót and the Jökulsá á Dal during the overflow of the Hálslón reservoir are silt-clay sized $(<60 \mu \mathrm{m})$ (see Fig. 8). Because of an exponential relationship between grain size and geometric surface area, the average specific surface area of the particles passing downstream through the power plant increased. Consequently, the particulate geometric surface area flux reduction due to the damming is less than the particle flux reduction, or $50 \%$. 
The particles discharged into to the coastal waters could release some elements to the ocean via dissolution or coupled adsorption/desorption. The particulate flux of non-soluble elements like $\mathrm{Fe}$, and to a lesser degree $\mathrm{Si}$, is likely to be more significant to the coastal water chemistry than those of soluble elements like $\mathrm{Na}, \mathrm{Ca}$, and $\mathrm{Mg}$ (Jeandel and Oelkers, 2015) since they are preferably transported to the oceans by particulates. Only a small dissolution or desorption from particulate material will dominate the input of non-soluble elements (e.g. Fe, P, Al, Ti) into seawater (Jeandel and Oelkers, 2015). After damming, the reduced mass flux of suspended particles likely lowers the release of less soluble micro nutrients to the coastal waters. However, the specific surface area of the particles arriving to the oceans are higher after damming due to their smaller grain size, which counteracts some of effect of overall lower particulate fluxes. If one considers nutrient and trace element release to be proportional to the surface area flux, one would expect an approximately 50\% reduction in the release of these elements to the oceans due to damming (Table 1).

\subsection{The mechanism of changing dissolved element fluxes}

After damming, an increase in the combined total flux of most dissolved elements of the Jökulsá á Dal and Lagarfljót was observed (Fig. 7). Some of this increase stems from increased runoff due to a warming climate during the study period (Gislason et al., 2009; Eiriksdottir et al., 2015), and/or enhanced melting of the Brúarárjökull glacier which retreated by $4.5 \mathrm{~km}$ after damming due to higher water pressure at the base of the glacier (Gunnarson et al., 2014). The average annual runoff increased by approximately 11\% between 1998-2003 and 2008-2013 (broken line on Fig. 7; Table 1), while it decreased by $8 \%$ in the control direct runoff river Fellsá (Fig. 1), consistent with a 9.7\% decrease in rainfall over this time (The Icelandic Meteorological Office, 2016). The combined fluxes of most dissolved elements in Jökulsá á 
Dal and Lagarfljót, however, increased by more than 11\% (Fig. 7). Major dissolved elements fluxes increased by $13-31 \%$ due to the damming.

As described above, the broken and the dotted lines in Fig. 6 represent the relative annual runoff change in the Jökulsá á Dal and Lagarfljót after damming relative to that prior to damming. Riverine fluxes are the product of runoff and riverine elemental concentrations so that flux changes can be both due to discharge and concentration changes. It can be seen in Fig. 6 that the relative flux change of about half of the measured components in the Lagarfljót are above the runoff change line (the broken line on Fig. 6) and have therefore increased by more than can be explained by the runoff increase alone. Similarly, the relative riverine flux change of the majority of the measured components in the Jökulsá á Dal is higher than the runoff change line which indicates that they have decreased less in the Jökulsá á Dal than can be explained by runoff changes alone. Thus, the combined flux increase of most of the dissolved elements (Fig. 7) is influenced by a concentration increase of these dissolved elements in the rivers. There are many factors contributing to the dissolved concentration increase in the various dissolved elements:

1) One contributor to the increase in dissolved element fluxes is a change in the saturation state of river waters with respect to the common secondary minerals in Icelandic soils, especially allophane. Calculations performed using PhreeqC together with the Gysi and Stefánsson (2011) thermodynamic database shows that the saturation state of allophane, a common $\mathrm{Al}-\mathrm{Si}$ secondary mineral in Icelandic soil, in the Jökulsá á Dal increases with increased discharge, implying that the water is supersaturated at high discharge and becomes undersaturated at low discharge (Fig. 9). Before damming, the Jökulsá á Dal discharge was high, leading to the allophane supersaturation; after damming this saturation state was lower. As the saturation state of allophane was lower after damming due to lower discharge, less is likely to precipitate 
and $\mathrm{Al}$ and $\mathrm{Si}$ such that these remain dissolved in the river compared to before damming. Moreover the saturation states of potentially dissolving phases including basaltic glass and olivine, pyroxene and plagioclase in the Jökulsá á Dal after damming are slightly more undersaturated than before damming, increasing their dissolution rates.

2) Another mechanism contributing to the increased total flux of dissolved elements in the rivers is the chemical weathering of suspended material in the Hálslón reservoir and Lagarfljót lagoon. This increase is supported by the observed changes in sodium fluxes in the Lagarfljót lagoon corrected for atmospheric input $\left(\mathrm{Na}^{*}\right)$, that increased substantially more than the runoff (Fig. 7; Table 1). Sodium is a soluble element that, after correction for atmospheric input, stems exclusively from catchment rock dissolution and is negligible taken up by secondary phases. The relatively high $\mathrm{Na}^{*}$ flux increase compared to the runoff (Fig. 6) indicates an increase in the dissolution of particulate matter within the reservoir and lagoon.

Chemical weathering in the Hálslón reservoir is likely slower than in the Lagarfljót because of its low temperature and as it is ice-covered much of the year. However, measurements of samples collected at depth in the reservoir, which is up to $170 \mathrm{~m}$ deep, indicate increasing element concentrations with depth, since the deep water tends to be stagnant and has therefore more time to react with the suspended particles, whose concentration also increases with depth (see Table A2 in the electronic annex). Increased water-rock interaction with depth causes $\mathrm{pH}$ to rise and the alkalinity and concentration of many major elements to increase. The oxygen level in the water also decreases with depth increasing the mobility of many metals including $\mathrm{Al}, \mathrm{Fe}, \mathrm{Mn}, \mathrm{Co}, \mathrm{Cr}, \mathrm{Cu}$ and $\mathrm{Ni}$, and as a by-product of increased mobility of $\mathrm{Fe}$, the mobility of phosphorus increases as well. This stagnant, more reacted deep water in the Hálslón reservoir is likely to be mixed within the entire reservoir during overturning of the water due to temperature gradients, thereby increasing the concentration of numerous elements in the 
Hálslón water. As the total mass of deep, stagnant water is only around $10 \%$ of the total reservoir volume (Thorkellsdóttir, 2001), this effect will only be large for those elements that are particularly concentrated in the deep waters such as Al, Fe, Mn, Co, Zn, and Ti (Table A2 in the electronic annex). Note the flux of these metals increased by 24 to $391 \%$, in the Jökulsá á Dal and Lagarfljót catchments.

3) A third factor increasing the dissolved element fluxes after damming is a decrease in the net primary production in the Lagarfljót lagoon. This leads to a lower uptake by the biota of essential nutrients including $\mathrm{Si}$ and $\mathrm{NO}_{3}$. Despite of increased water flux, the concentration of $\mathrm{SiO}_{2}$ in summer samples collected from the Lagarfljót increased by 10-15\% due to damming (Fig. 10). Further, the concentration of $\mathrm{NO}_{3}$ in summer samples in Lagarfljót was on average three times higher after damming (Eiriksdottir et al., 2015 and Table A2), indicating less uptake of nutrients by biota after damming. This observation could be attributed to lower silica phytoplankton production in the lagoon (Hansen et al. 2013). The penetration of light into the lagoon is 50-70 \% less due to damming (Adalsteinsson and Bodvarsdottir, 2014) because of a higher concentration of suspended matter. Moreover, recent work indicates that the freshwater char stock in the Lagarfljót declined by 60-70\% from 2005-2006 to 2011-2012 (Jónsson et al., 2013). This finding is in concert with the flux changes in $\mathrm{NO}_{3}$ and $\mathrm{N}$-total shown in Figure 6 . In contrast, the fresh water salmon stock in Jökulsá á Dal has grown after damming because of the removal of the glacial water from the river channel (Gudbergsson and Njardardottir, 2014).

Decreased net primary production is also reflected in the concentration of total $\mathrm{N}$, which is the sum of dissolved organic and inorganic N. The flux of total dissolved $\mathrm{N}$ decreased while the flux of dissolved $\mathrm{NO}_{3}$ increased to a similar extent. The flux of $\mathrm{NH}_{4}$, the other major inorganic $\mathrm{N}$ species, was unchanged. A decrease in $\mathrm{NO}_{3}$ consumption by photosynthesizing organisms after damming, due to higher particulate load and lower water transparency in the 
Lagarfljót, leads to decreased organic N production in the lagoon and thus, a higher riverine $\mathrm{NO}_{3}$ flux. The particulate organic matter (POC and PON) fluxes have, however, increased, possibly due to increased erosion on the banks of the Lagarfljót due to increased discharge after damming (Thorarinsdottir and Einarsson, 2012).

In contrast to the combined total dissolved $\mathrm{N}$ fluxes (N-total), fluxes of total dissolved $\mathrm{P}$ (P-total) fluxes increased and the $\mathrm{PO}_{4}$ flux decreased in the river catchments (Fig. 7). The increased P-total flux is proportional to the decreased $\mathrm{PO}_{4}$ flux. This can be explained by the surface reactivity of $\mathrm{PO}_{4}$. Increased residence time promotes $\mathrm{PO}_{4}$ adsorption onto inorganicand organic colloids (Ruttenberg, 2003) and thus increases the P-total concentration. The phosphorus concentration in glacial rivers has been shown to be higher than in non-glacial rivers due to the weathering of fine grained glacial sediments and a limited vegetation cover (Gislason et al., 1996; Hodson et al, 2004; Hood and Berner 2009; Eiriksdottir et al., 2015). This is evident in Fig. 3, where the overflow of the Hálslón reservoir, which has a high $\mathrm{PO}_{4}$ concentration compared to the non-overflow water in Jökulsá á Dal, adds substantially to the annual flux of total dissolved P of the Jökulsá á Dal.

\subsection{Increased filterable Fe and and Ti fluxes after damming}

The annual flux of filterable Fe (Raiswell and Canfield, 2012) and Ti of the combined Jökulsá á Dal and Lagarfljót rivers increased by $391 \%$ and 251\%, respectively, which is far more than the annual flux change of other dissolved elements (Figs. 5 and 8 and Table 1). The term "filterable" in this context refers to that which passes through the $0.2 \mu \mathrm{m}$ filter used during sampling. Iron and Ti commonly form 0.01-1 $\mu \mathrm{m}$ colloids (Raiswell and Canfield, 2012) such that a large part of these elements could pass through the $0.2 \mu \mathrm{m}$ filters used in this study. Ultrafiltration can distinguish the truly dissolved from the colloidal Fe and Ti fraction (Pokrovsky and Schott, 2002; Raiswell and Canfield, 2012). Iron colloids can form by the oxidation of $\mathrm{Fe}^{2+}$ 
in surface waters (e.g. Pokrovsky and Schott, 2002). The first iron phase to form by this process is iron(oxy)hydroxide colloids. Other elements (e.g. $\mathrm{Mn}, \mathrm{Ni}, \mathrm{Cu}, \mathrm{Cd}, \mathrm{Al}$, and $\mathrm{Ti}$ ) can coprecipitate with the Fe (Pokrovsky and Schott, 2002). These colloids are very surface reactive and tend to be adsorbed on other surfaces (Raiswell and Canfield, 2012).

Overall, there is an increase in the filterable Fe concentration in the Jökulsá á Dal after dam construction. This increase is especially large during the spring melt, causing a high Fe flux in the river. During the spring, the rivers' discharge is dominated by snowmelt at low elevations in the catchments. The average Fe concentration in Jökulsá á Dal was higher than in the control river Fellsá by a factor of two and nine before and after damming, respectively. The most likely explanation for the filterable Fe flux increase in the Jökulsá á Dal after damming is the removal of fine grained, suspended particles from the river which, before damming, would have adsorbed Fe colloids from the water. Iron colloids adsorbed onto particles would be filtered out in the samples preparation. This possibility is supported by the particle compositions, which show that the Fe content of suspended particles in the Jökulsá á Dal is higher during the winter/spring than during the summer/autumn (Eiriksdottir et al., 2008). Before damming, the total geometric surface area of the suspended matter winter/spring samples in the Jökulsá á Dal was up to seven times higher than during the summer/autumn and the particulate samples with the highest surface area also have the highest Fe concentration. Comparison of $\mathrm{Age}_{\text {geo }}$ and measured BET (Brunauer et al., 1938) surface area of the particulate matter collected from Jökulsá á Dal before damming reveal a surface roughness up from 30 to 200, further suggesting the presence of iron(oxy)hydroxides; note that ion(oxy)hydroxides have far higher specific surface areas than other suspended particles (Table A3 in the electronic annex). This hypothesis is also supported by the observation that the Jökulsá á Dal is supersaturated with respect to amorphous goethite (PhreeqC) before and after the damming, especially during spring after 
damming. Additionally, the runoff dependene of the dissolved iron fluxes after damming reveals that the filterable Fe flux behaves similarly to the particulate matter flux. This is reflected by the slope of the runoff dependency of the relative iron flux which is greater than 1 . Eiriksdottir et al. (2015) concluded that this behaviour is due to the presence of substantial colloidal iron.

The calculated dissolved titanium flux increase after damming is due to a filterable Ti concentration increase in both the Jökulsá á Dal and the Lagarfljót. There is a relatively large Ti spring flux peak in the Jökulsá á Dal, which has the same shape as the Fe spring flux peak. As it is similar to the Fe spring flux peak, it is likely to be due to colloidal adsorption onto particulates after damming. Additionally, there is an even larger Ti flux peak in the autumn, when the Hálslón reservoir is overflowing into the Jökulsá á Dal river channel (Fig. A2 in the electronic annex). A similar behaviour can also be seen in the water samples collected from the outlet of the Hálslón reservoir, before the water enters the Lagarfljót (Table A2 in the electronic annex). The average Ti concentration in the control river Fellsá was higher during 1998-2003 than during 2008-2013, but the dissolved Ti concentration in the Lagarfljót was higher than in Fellsá by factors three and eight before and after damming, respectively. As discussed in section 3.2, dissolution of suspended inorganic matter in the deep, stagnant water of the Hálslón reservoir causes increased $\mathrm{pH}$ and concentration of many major elements. The water becomes reduced with depth, which mobilizes many metals. The Ti concentration of the deepest water in this reservoir was more than 50 times higher than in the shallow water (Eiriksdottir et al., 2014; Table A2 in the electronic annex). The overturning of the water column mixes the deep water with the rest of the water body, increasing the overall $\mathrm{Ti}$ concentration of the Hálslón reservoir, given that Ti secondary phase precipitation is slow. The 
Ti concentration in water from the outlet of the reservoir is on average five times higher than that before damming (Table A2 in the electronic annex; Eiriksdottir et al., 2015).

\subsection{The timing of the riverine dissolved silica flux to the coastal ocean}

As sunlight increases in the spring, primary productivity increases in the Icelandic coastal waters. The spring diatom bloom consumes dissolved silica in such large quantities that silica becomes the limiting nutrient for diatom primary production (Ólafsson et al., 2008). The melting of snow during the spring increases river discharge and the fluxes of numerous river constituents to the coast, including that of silica. In this way the abrupt spring water flow peak is important for primary production in the coastal waters. In addition, phytoplankton communities are sensitive to nutrient load changes. Depletion of silica relative to $\mathrm{N}$ and $\mathrm{P}$ has caused decreased silicate diatom blooms and increased blooms of non-diatom phytoplankton (Conley et al., 1993), similar to what has happened in Scandinavian coastal waters (Maestrini and Granéli, 1991).

Despite substantial annual flux changes due to the damming of the Jökulsá á Dal, as spring snow melt in Iceland is dominated by low elevation melting, the dissolved Si spring fluxes are relatively unaffected by the presence of the dam, which is located at $625 \mathrm{~m}$ a.s.l. (see Figs. 3 and 5). In fact, the dissolved spring fluxes of $\mathrm{Si}, \mathrm{Fe}, \mathrm{P}$-total (Fig. 5) and $\mathrm{NO}_{3}$ (Fig. A3b in the electronic annex) increased after damming. However, the dissolved spring N-total fluxes are slightly lower after damming because of lower water transparency and primary production in the Lagarfljót lagoon. Taken together it seems likely that the construction of this dam will have relatively little effect on the spring silica diatom bloom off the Icelandic coast.

\subsection{Comparison of damming in a glacial vs. non-glacial rivers}


Glacial rivers differ from non-glacial river in numerous ways. They have very seasonal discharge and, unlike non-glacial rivers, carry larger amounts of fine grained, inorganic suspended matter. Reservoirs in glacial rivers have shorter operation time than in non-glacial rivers due to a high sedimentation rate in the reservoirs. Therefore, and due to high seasonal fluctuations, reservoirs in glaciated catchments need to be large. Greenhouse-gas emission from man-made reservoirs can be of concern, especially when located in areas with thick, organic soil. Soil development in the vicinity of an active glacier is slow, and glacial river damming in the vicinity of the glacier is therefore not likely to cause high emissions of greenhouse-gases due to organic matter decay occurring at the bottom of the reservoir (Óskarsson and Gudmundsson, 2001; 2008; Gisladottir et al., 2014).

Damming a glacial river catchment causes accumulation of large amounts of particulate matter, which would otherwise have been carried to the ocean. That affects the particulate flux of non-soluble elements to the coastal waters (Oelkers et al., 2012; Jones et al., 2012a; 2012b; Jeandel and Oelkers, 2015), of which many are essential nutrients (e.g. Falkowski, 2003). Reduction of riverine particulate transport due to damming of glacial rivers can thus diminish the fertility of the coastal waters. Further, glacial rivers are an important source of sand to the shorelines which, if dammed, can lead to coastal erosion (Pilkey et al., 2011).

Photosynthesis and nutrient uptake in reservoirs on glaciated catchments is low because of their high concentration of suspended matter, and limited transparency. This contrasts with reservoirs in non-glacial river catchments, which have higher transparency allowing more photosynthesis and nutrient uptake within the reservoir, and enhanced production of organic matter. The decomposition of this organic matter consumes oxygen and may cause anoxia at the reservoir bottom. Apart from the threat of hypoxia to aquatic organisms, concentrations of redox sensitive metals can increase to a toxic level (Stumm and Morgan, 1996). The diversion 
of the water from the glacial catchment of Jökulsá á Dal to the partially glaciated catchment of Lagarfljót has caused calmer water flows and enhanced nutrient uptake due to photosynthesis in the former. The diverted glacial water from Hálslón reservoir, with its' high particulate load, decreased the transparency and photosynthesis in the Lagarfljót lagoon and thus, lowered nutrient uptake as evidenced by increased $\mathrm{Si}$ and $\mathrm{NO}_{3}$ fluxes after damming.

\section{Conclusion}

This study explored the chemical consequences of damming on the glacial river Jökulsá á Dal, and diverted water flow to the partially glaciated Lagarfljót in Eastern Iceland. This system is particularly complex, as the dam construction diverted glacial water from one river catchment to the other, changing substantially the nature of the two rivers. The impact of damming on the combined riverine fluxes to the ocean can be summarised as follows:

1. Five Mt/yr of inorganic suspended matter is trapped annually in the Hálslón reservoir behind the dam. Coarse grained material $(60-200 \mu \mathrm{m})$ tends to be trapped compared to the fine grained particles $(<60 \mu \mathrm{m})$. Therefore the overall grain size of particulates transported to the oceans decreased. Consequently, although the total mass of particulate material transported to the oceans decreased by $85 \%$, the total particle geometric surface area flux of the combined two rivers, has decreased by $\sim 50 \%$. As the reactivity of these particles in the ocean is likely proportional to their grain size, the smaller average size of these particles may counteract the environmental effects of decreasing particulate transport.

2. Most dissolved element fluxes to the ocean increased, including those of the micro- and macro-nutrients $\mathrm{Fe}, \mathrm{Si}$ and $\mathrm{NO}_{3}$. This increase is interpreted to originate from:

a. increased runoff due to increased melt water. 
b. the effect of lowering mineral saturation states of river water with respect to common secondary minerals within the catchments, and to a lesser degree, primary minerals.

c. increased residence time of the river water and suspended particulate matter due to the presence of the Hálslón Reservoir and the diversion into the Lagarfljót catchment.

d. increased mobilization of metals due to decreased oxygen concentrations in the deep part of the Hálslón Reservoir.

e. decreased photosynthesis caused by an increase in inorganic suspended matter concentration preventing light penetration into the Lagarfljót lagoon.

3. The Icelandic coastal waters have lower silica concentration than the rivers. Thus riverine silica flux is important for the silica diatom bloom, especially during spring. Despite huge flux changes due to damming of the Jökulsá á Dal, this has not affected the timing of the spring Si flux to the oceans due to the fact that the spring flux is dominated by snow melting occurring below the dam.

\section{Acknowledgements}

This study was funded by the Landsvirkjun, the National Power Company of Iceland, the Ministry for the Environment and Natural Resources in Iceland, and the University of Iceland Research Fund (2013 and 2014). In particular we would like to thank Hákon Adalsteinsson, Theodór Thedórsson, Óli Grétar Blöndal Sveinsson, Sigmundur Freysteinsson, Helgi Jensson, Davíð Egilsson and Gunnar Steinn Jónsson. We would like to thank our collaborators at the Hydrological Service at the Metorological Office in Iceland, the Institute of Earth Sciences, University of Iceland and CNRS in Toulouse, especially Svava Björk Porláksdóttir, Gunnar Sigurðsson, Sverrir Elefsen, Egill Axelsson, Ingvi Gunnarsson, Bergur Sigfússon, Rebecca 
Neely, Iwona M. Galecza and Sandra Ó. Snæbjörnsdóttir for their help and support during this study. Special thanks to Daði Porbjörnsson for discussions and constructive comments on the manuscript. Two anonymous reviewers are thanked for constructive comments during the review process. 


\section{References}

Adalsteinsson H. and Bödvarsdottir E. B. (2014) Endurmat á gegnsai í Lagarfljóti fyrir og eftir gangsetningu Kárahnjúkavirkjunar. (e. Re-estimate on transparency in Lagarfljót before and after the onset of the Kárahnjúkavirkjun power plant), Landsvirkjun LV-2014074, 11 pp. In Icelandic.

Allègre C., Louvat P., Gaillardet J., Meynadier L., Rad S., Capmas F. (2010) The fundamental role of island arc weathering in the oceanic Sr isotope budget. Earth Planet. Sci. Lett. 292, 51-56.

Aller, R. (1998) Mobile deltaic and continental shelf muds as suboxic, fluidized bed reactors. Mar.Chem. 61,143-155.

Arsouze T., Dutay J.-D., Lacan F., Jeandel C. (2009) Reconstructing the Nd oceanic cycle using a coupled dynamical-biogeochemical model. Biogeosciences 6, 1-18.

Brunauer S., Emmett P, H., and Teller E. (1938) Adsorption of Gases in Multimolecular Layers. J. Am. Chem. Soc. 60, 309-319.

Conley D. J., Schelske C. L., Stoermer E. F. (1993) Modification of the biogeochemical cycle of silica with eutrophication. Mar. Ecol. Prog. Ser. 101, 179-192.

Eiriksdottir E. S., Louvat P., Gislason S. R., Óskarsson N, Hardardóttir J. (2008) Temporal variation of chemical and mechanical weathering in NE Iceland: Evaluation of a steadystate model of erosion. Earth Planet. Sci. Let. 272, 78-88.

Eiriksdottir E. S., Gislason S. R., Snorrason Á., Hardardottir J., Thorlaksdottir S. B., Sveinbjornsdottir A. E., Neely R. A. (2014) Efnasamsetning, rennsli og aurburður í vatnsföllum á Austurlandi XI. Gagnagrunnur Jarðvísindastofnunar og Veðurstofunnar. (e. Chemical composition, discharge and suspended particulates in rivers in East Iceland. 
Database of the Institute of Earth Sciences and the Meteorological Office Iceland). Report RH-05-2014. 126 pp. (In Icelandic).

Eiriksdottir E. S., Gislason S. R. and Oelkers E. H. (2013) Does temperature or runoff control the feedback between chemical denudation and climate? Insights from NE Iceland. Geochim. Cosmochim. Acta 107, 65-81.

Eiriksdottir E. S., Gislason S. R. and Oelkers E. H. (2015) Direct evidence of the feedback between climate and nutrient, major, and trace element transport to the oceans. Geochim. Cosmochim. Acta 166, $249-266$.

Elrod, V. A., Berelson, W. M., Coale, K. H., Johnson, K. S. (2004) The flux of iron from continental shelf sediments: a missing source for global budgets. Geophys. Res. Lett. 31, L12307, http://dx.doi.org/10.1029/2004GL020216.

Falkowski P. G., Barber, R. T. and Smetacek, V. (1998) Biogeochemical controls and feedbacks on ocean primary production. Science 281, 200 - 206.

Falkowski P. G. (2003) Biogeochemistry of Primary Production in the Sea. In Biogeochemistry (ed. W. H. Schlesinger) Vol. 8. Treatise on Geochemistry (eds. H. D. Holland and K. K. Turekian), Elsevier - Pergamon, Oxford, pp. 185 - 213.

Friedl G. and Wüest A. (2002) Disrupting biogeochemical cycles - Consequences of damming. Aquat. Sci. 64, 55-65.

Gaillardet J., Dupré B., Louvat P., Allègre C. J. (1999) Global silicate weathering and $\mathrm{CO}_{2}$ consumption rates deduced from the chemistry of large rivers. Chem.Geol. 159, 3-30.

Gisladottir G., Mankasingh U. and Pórsson J. (2014) Physical and chemical soil properties of different land cover types, related to soil carbon, at Sporð̈ldulón. RH-06-2014. Report Institute of Live and Environmental Sciences, University of Iceland. 27 pp. 
Gislason S. R. Arnórsson S. and Armannsson H. (1996) Chemical weathering of basalt as deduced from the composition of precipitation, rivers, and rocks in SW Iceland. Am. J. Sci. 296, 837-907.

Gislason S. R., Oelkers E. H. and Snorrason Á. (2006) The role of river suspended material in the global carbon cycle. Geology 34, 49-52.

Gislason S. R., Oelkers E. H., Eiriksdottir E. S., Kardjilov M. I., Gisladottir G., Sigfusson B., Snorrason A., Elefsen S. O., Hardardottir J., Torssander P. and Oskarsson N. (2009) Direct evidence of the feedback between climate and weathering. Earth Planet. Sci. Lett. 277, $213-222$.

Gudbergsson G. and Njardardottir E. (2014) Útbreiðsla og ástand seiða í Jökulsá á Dal og hliðarám hennar 2013 (e. Distribution and condition of juvenile fresh water fish in Jökulsá á Dal in 2013). Report in Icelandic. VMST/13048. 28 pp.

Gunnarsson A., Theódórsson T., Pórhallson R., Xuyi J. B., Jónsson G. P. (2014)

Sniðmælingar Hálslóns sumarið 2013 (e. profile measurements in Hálslón summer 2013). LV-2014-050, report in Icelandic, 20 bls.

Gupta H., Kao S-J, Dai M. (2012) The role of mega dams in reducing sediment fluxes: A case study of large Asian rivers. J. Hydro. 464-465, 447-458.

Guy, H. P. and Norman, V. W. (1970) Techniques of Water-Resources Investigations of the United States Geological Survey. Field Methods for Measurement of Fluvial Sediment 3 (C2). United States Government Printing Office, Washington, D.C.

Gysi A. P. and Stefánsson A. (2011) $\mathrm{CO}_{2}-$ water-basalt interaction. Numerical simulation of low temperature $\mathrm{CO}_{2}$ sequestration into basalts. Geochim. Cosmochim. Acta 75, 4728 4751.

Hansen I, Njardardottir E., Ingimarsson F., Ingvason H. R., and Ólafsson J. S. (2013) Kísilpörungar og smádýr í Latarfljóti 2006-2007 (e. Silica diatoms and invertebrates in 
Lagarfljót 2006-2007). A report in Icelandic. Institute of Freshwater Fisheries, Natural History Museum of Kópavogur, 78 pp.

Hodson, A., Mumford P. and Lister D. (2004) Suspended sediment and phosphorus in proglacial rivers: Bioavailability and potential impacts upon the $\mathrm{P}$ status of ice-marginal receiving waters. Hydrol. Process. 18, 2409-2422.

Hood E. and Berner L. (2009) Effects of changing glacial coverage on the physical and biogeochemical properties of coastal streams in southeastern Alaska. J. Geophys. Res. 114, GO3001.

Holland H. D. (2005) Sea level, sediments and the composition of seawater. Am. J. Science $305,220-239$.

Jickells T. D. (1998) Nutrient Biogeochemistry of the Coastal Zone. Science 10, 217 - 222.

Jeandel C., Peucker-Ehrenbrink B., Jones M. T., Pearce C. R., Oelkers E. H., Godderis Y., Lacan F., Aumont O., Arsouze T. (2011) Ocean margins: the missing term for oceanic element budgets? EOS 92, 217-219.

Jeandel C. and Oelkers E. (2015) The influence of terrigenous particulate material dissolution on ocean chemistry and global element cycles. Chem. Geol. 395, 50-66.

Jones M. T., Pearce C. R., Oelkers E. H. (2012a) An experimental study of the interaction of basaltic riverine particulate material and seawater. Geochim. Cosmochim. Acta, 77, 108120.

Jones M. T., Pearce C. R., Jeandel C., Gislason S. R., Eiriksdottir E. S., Mavromatis V., Oelkers E.H. (2012b) Riverine particulate material dissolution as a significant flux of strontium to the oceans. Earth Planet. Science Let. 355-356, 51-59.

Jones M. T., Gislason S. R., Burton K. W., Pearce C. R., Mavromatis V., Pogge von Strandmann P. A. E., Oelkers E. H. (2014) Quantifying the impact of riverine particulate dissolution in seawater on ocean chemistry. Earth Planet. Sci. Letters 395, 91-100. 
Jónsson I. R., Árnason F. and Guðbergsson G. (2013) Fiskirannsóknir á vatnasviði Lagarfljóts, Jökulsár á Dal, Fögruhlíðarár og Gilsár 2011-2012 (e. Fish research on the catchments of Lagarfljót, Jökulsá á Dal, Fögurhlíđará and Gilsá 2011-2012). LV-2013084.

Kardjilov M. I., Gislason S. R., Gisladóttir G. (2006) The effect of gross primary production, net primary production and net ecosystem exchange on the carbon fixation by chemical weathering of basalt in northeastern Iceland. J. Geochem. Expl. 88, 292-295.

Kardjilov M. I. (2008) Riverine and terrestrial carbon fluxes in Iceland. Doctoral Thesis from the department of geography and tourism, University of Iceland. Reykjavik, $83 \mathrm{pp}$.

Landsvirkjun (2009) Kárahnjúkavirkjun Power Plant and Fljótsdalsstöð, Power Station in numbers. http://www.landsvirkjun.is/Fyrirtaekid/Fjolmidlatorg/Frettir/Frett/857_/

Maestrini S, Granéli E (1991) Environmental conditions and ecophysiological mechanisms which led to the 1988 Chrysochromulina polylepis bloom: an hypothesis. Oceanol Acta 14, $397-413$.

Martin J. H., Gordon R. M., Fitzwater S. E. (1991) The case for iron. Limnology and Oceanography 36, 1793-1802

Milliman J. D. and Syvitski J. P. M. (1992) Geomorphic/Tectonic Control of Sediment Discharge to the Ocean: The importance of Small Mountainous Rivers. J. Geol. 100, 525 $-544$.

Morel F. M. M., Milligan A. J., Saito M. A. (2003) Marine bioinorganic chemistry: the role of trace metals in the oceanic cycles of major nutrients. In: The Oceans and Marine Geochemistry. Vol 6. Treatise on Geochemistry. (Holland, H. D., Turekian, K. K. eds.) Elsevier - Pergamon, Oxford, pp. 113-143

Morin G. P., Vigier N., Verney-Carron A. (2015) Enhanced dissolution of basaltic glass in brackish waters: Impact on biogeochemical cycles. Earth Planet. Sci. Lett. 417, 1-8. 
Nilsson C., Reidy C. A., Dynesius M., Revenga C. (2005) Fragmentation and Flow Regulation of the World's Large River Systems. Science 308, 405-408.

Noble A.E., Saito M. A., Maiti K., Benitez-Nelson C.R. (2008) Cobalt, manganese and iron near the Hawaiian Islands: a potential concentrating mechanism for cobalt within a cyclonic eddy and implication for the hybrid-type trace metals. Deep Sea Res. II 55, 14731490.

Oelkers E. H., Gislason S. R., Eiriksdottir E. S., Jones M. T., Pearce C. R., Jeandel C. (2012) Riverine particulate material dissolution in seawater and its implications for the global cycles of the elements. Compt. Rendus Geosci. 344, 646-651.

Ólafsson J., Ólafsdóttir S. R. and Briem J., 2008. Vatnsföll og vistkerfi strandsjávar. Náttúrufraeðingurinn, 76, 95-108.

Oskarsdottir S. M. Gislason S. R., Snorrason A., Halldorsdottir S. G., Gisladottir G. (2011) Spatial distribution of dissolved constituents in Icelandic river waters. J. Hydro. 397, 175190.

Óskarsson H. and Gudmundsson J., (2001). Mat á gróðurhúsaáhrifum fyrirhugaðs Hálslóns. (e. Estimates on greenhouse effects of Hálslón reservoir). Report, LV-2001/019 Agricultural University of Iceland and Landsvirkjun powerplant, $31 \mathrm{pp}$. In Icelandic.

Óskarsson H. and Gudmundsson J., (2008). Gróðurhúsaáhrif uppistöðulóna. Rannsóknir við Gilsárlón 2003-2006 (e. Greenhouse effects of reservoirs. Data from Gilsárlón 20032006). Landsvirkjun, LV-2008/028. 142 pp. In Icelandic.

Pálsson S. and Vigfússon G. H. (1996) Gagnasafn aurburðarmælinga 1963-1995 (e. Results of suspended load and discharge measurements 1963-1995). Reykjavik, National Energy Authority, OS-96032/VOD-05 B. In Icelandic. 
Pálsson S., Hardardóttir J, Vigfússon G. H. and Snorrason Á. (2000). Reassessment of suspended sediment load of river Jökulsá á Dal at Hjarðarhagi. Report Orkustofnun OS2000/070, Reykjavik, Iceland.

Pearce C. R., Jones M. T., Oelkers E. H., Pradoux C., Jeandel C. (2013) The effect of particulate dissolution on the neodymium $(\mathrm{Nd})$ isotope and Rare Earth Element (REE) composition of seawater. Earth Planet. Sci. Lett. 369-370, 138-147.

Peucker-Ehrenbrink B., Miller M. W., Arsouze T., and Jeandel C. (2010) Continental bedrock and riverine fluxes of strontium and neodymium isotopes to the oceans. Geochemistry, Geophysics, Geosystems, 11, Q03016, 10.1029/2009GC002869

Pilkey O. H., Neal W. J., Kelley J. T., Cooper J. A. G. (2011) The World's Beaches: A Global Guide to the Science of the Shoreline. University of California Press, Berkeley, CA (2011) (283 pp.)

Pokrovsky O. S. and Schott J. (2002) Iron colloids/organic matter associated transport of major and trace elements in small boreal rivers and their estuaries (NW Russia). Chem. Geol. 190, 141-179.

Raiswell R. and Canfield D. E. (2012) The Iron Biogeochemical Cycle Past and Present. Geochem. Perspectives 1, 220 pp.

Ruttenberg K. C. (2003) The global phosphorus cycle. In Treatise on Geochemistry, vol. 8. Biogeochem. (eds. W. H. Schlesinger, H.D. Holland and K.K. Turekian), Elsevier Pergamon, Oxford, pp. $585-643$.

Singh S. P., Singh S. K., Goswami V., Bhushan R., Rai V. K. (2012) Spatial distribution of dissolved neodymium and $\varepsilon_{\mathrm{Nd}}$ in the Bay of Bengal: role of particulate matter and mixing of water masses. Geochim. Cosmochim. Acta 94, 38-56. 
Statistics Iceland (2016) Number of inhabitants in Eastern Iceland. Webpage, 19.08.2016. http://px.hagstofa.is/pxis/pxweb/is/Ibuar/Ibuar_mannfjoldi_2_byggdir_sveitarfelog/M AN02001.px/

Stefansdottir M. and Gislason S. R. (2005) Suspended basaltic glass-seawater interactions. J. Geochem. Expl. 88, 332-335.

Stumm W. and Morgan J. J. (1996) Aquatic Chemistry. Chemical Equilibria and Rates in Natural Waters, 3rd ed. John Wiley \& Sons Inc, 1022 p.

Syvitski J. P. M., Vörösmarty C. J., Kettner A. and Green P. (2005) Impact of Humans on the Flux of Terrestrial Sediment to the Global Coastal Ocean. Science 308, 376 - 380.

The Icelandic Meteorological Office (2014) Database of the MET office, delivery no. 2014$05-22 / 01$

The Icelandic Meteorological Office (2016) Database of the MET office, 19/8/2016. http://www.vedur.is/Medaltalstoflur-txt/Stod_527_Skjaldtingsstadir.ArsMedal.txt

Thorarinsdottir E. F. and Einarsson S. (2012) Skráning á landbroti á bökkum Lagarfljóts og Jökulsár í Fljótsdal (e. Observation of erosion on the banks of Lagarfljót and Jökulsá í Fljótsdal). LV-2012-109. A report in Icelandic. 54 pp.

Thorkellsdóttir H. K. (2001) Kárahnjúkavirkjun: Lónkúrfa Hálslóns [e. the reservoir curve]. VST, Reykjavík.

Tómasson H. (1990) Suspended material in Icelandic rivers, in Guttormur, S., ed., Vatnid og Landid: Reykjvík, Orkustofnun, p. 169-174.

Tómasson G.G. and Hardardóttir J. (2001) Kárahnjúkavirkjun, áhrif á lit Lagarfljóts, niðurstöður tilrauna. OS-2001/016, 19 pp.

Tréguer P., and de la Rocha C. L. (2013) The world ocean silica cycle. Annu. Rev. Mar. Sci. 268, 375-379. 
Vörösmarty C. J., Meybeck M., Fekete B., Keshav Sharma, Green P., Syvitski J. P. M. (2003) Anthropogenic sediment retention: major global impact from registered river impoundments. Global Planet. Change 39, 169-190.

Walling D. E. and Fang D. (2003) Recent trends in the suspended sediment loads of the world's rivers. Global Planet. Change 39, 111-126.

Walling D. E. (2006) Human impact on land - ocean sediment transfer by the world's rivers. Geomorph. 79, $192-216$.

Wang H., Yang Z., Wang Y., Saito Y., Liu J. P. (2008) Reconstruction of sediment flux from the Changjiang (Yangtze River to the sea since the 1860s. J. Hydro. 349, 318-332.

Wang H., Bi N., Saito Y., Wang Y., Sun X., Zhang J., Yang Z. (2010) Recent changes in sediment delivery by the Huanghe (Yellow River) to the sea: Causes and environmental implications in its estuary. J. Hydro. 391, 302-313.

Wolff-Boenisch D., Gislason S. R., Oelkers E. H. (2004) The effect of fluoride on the dissolution rates of natural glasses at $\mathrm{pH} 4$ and $25^{\circ} \mathrm{C}$. Geochim. Cosmochim. Acta, $\mathbf{6 8}$, $4571-4582$.

Yang S. L., Milliman J. D., Li P. and Xu K. (2011) 50,000 dams later: Erosion of the Yangtze River and its delta. Global Planet. Change 75, 14-20. 


\section{Figure captions}

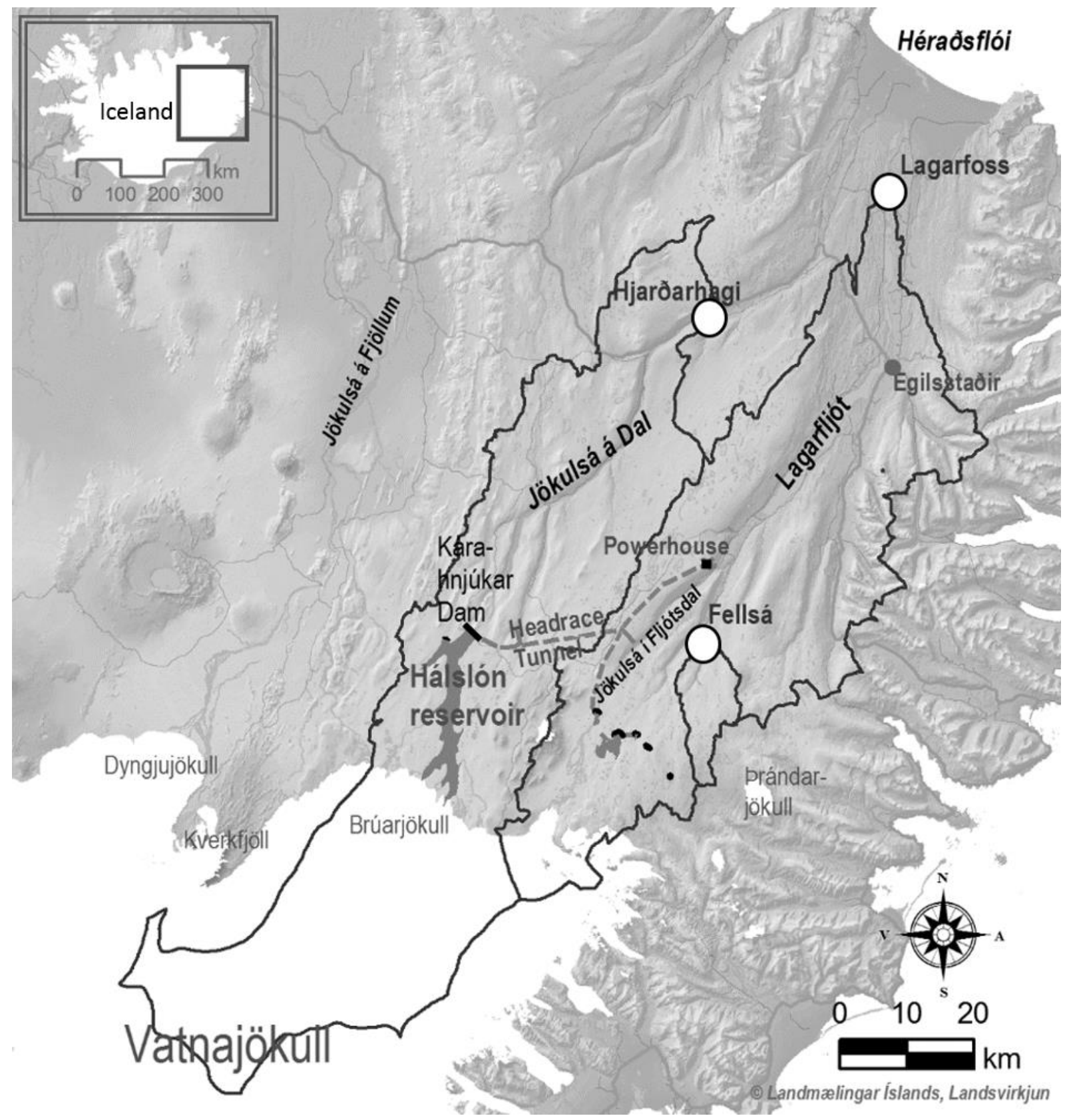

Figure 1. Maps showing the location of the two river catchments affected by the damming of the glacial river Jökulsá á Dal in Eastern Iceland, the location of the sampling sites (white circles), the Hálslón reservoir (dark grey area) created by the dam (black thick line), the headrace tunnels (grey hatched curves) and the power plant (black square). Also shown is the location of Fellsá river catchment, an undisturbed river used as a control in this study. The 
Vatnajökull glacier is shown in white in the lower left corner (map from the National Land Survey of Iceland and Landsvirkjun, National Power Company of Iceland).
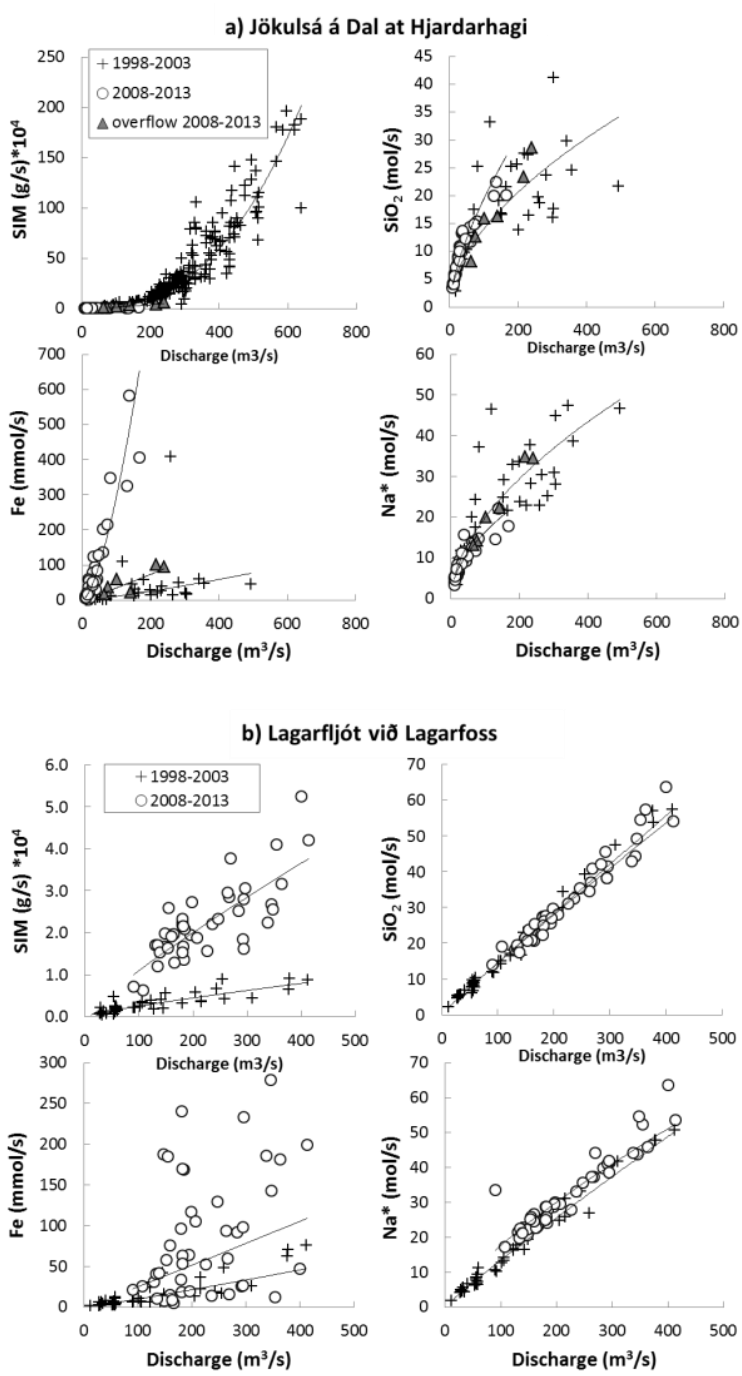

Figure 2. The discharge dependence of the instantaneous flux before (crosses) and after damming (open circles and grey triangles) of suspended inorganic material (SIM) and dissolved $\mathrm{SiO}_{2}, \mathrm{Na}$ and $\mathrm{Fe}$ in a) the Jökulsá á Dal at Hjardarhagi and b) the Lagarfljót at Lagarfoss . The Na flux is corrected for atmospheric input $\left(\mathrm{Na}^{*}\right)$. The data from the Jökulsá á Dal during 2008- 
2013 are divided into two groups, one with (grey triangles) and one without (open circles) overflow from the Hálslón reservoir. The discharge-flux relationships, indicated by the curves on the figure, (equations given in Table A1) were used together with the average daily discharge to calculate the daily- and annual element river fluxes (see Table 1).

\section{Jökulsá á Dal at Hjardarhaga}
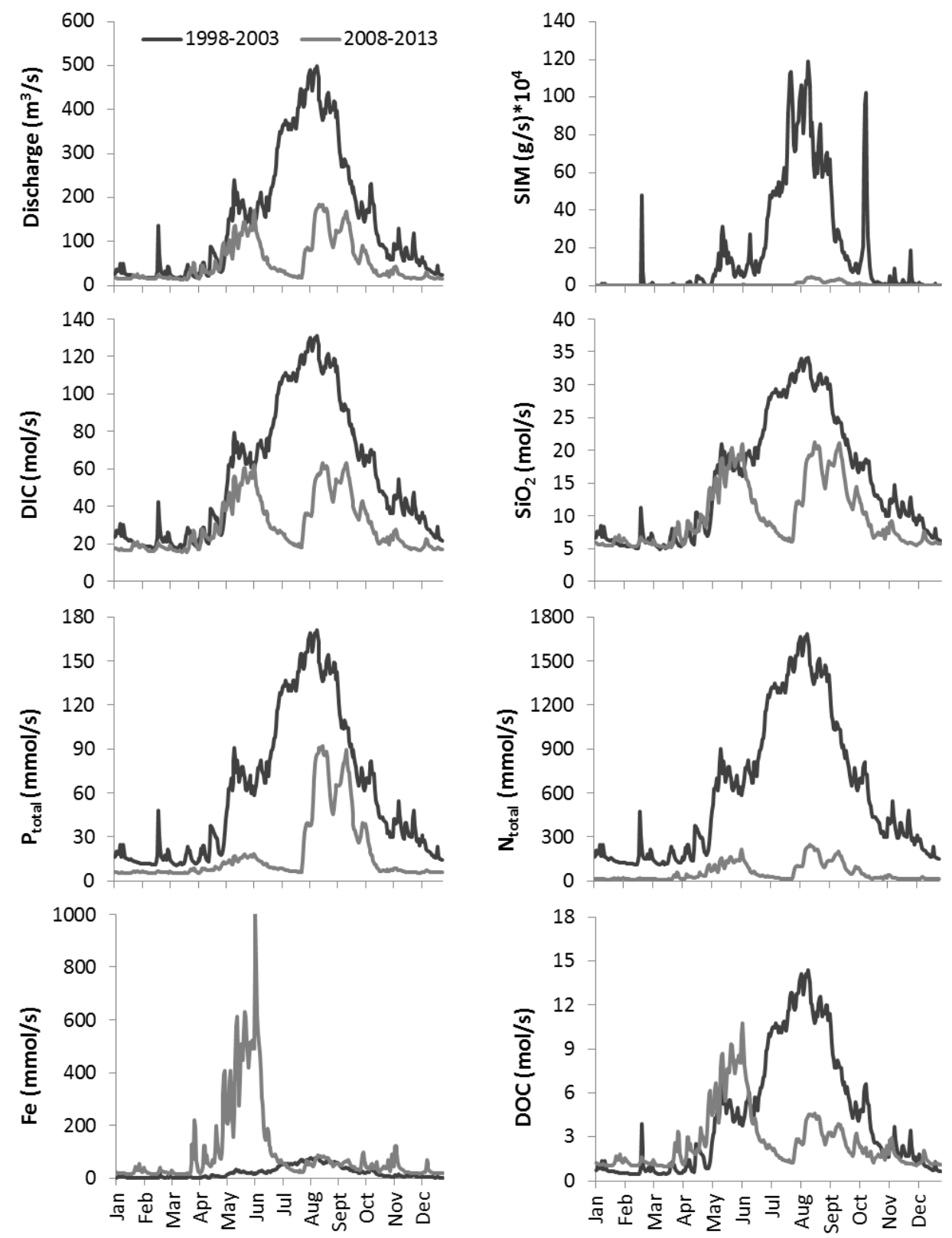
Figure 3. The average daily discharge and suspended- and dissolved flux in the Jökulsá á Dal at Hjardarhagi before (dark grey) and after (light grey) damming - see text. Before damming, the discharge and riverine fluxes were highest during peak summer months during glacial melting. After damming, there are two peaks during the year, first during snow melt in spring and then again when the Hálslón reservoir overflows.

\section{Lagarfljót at Lagarfoss}

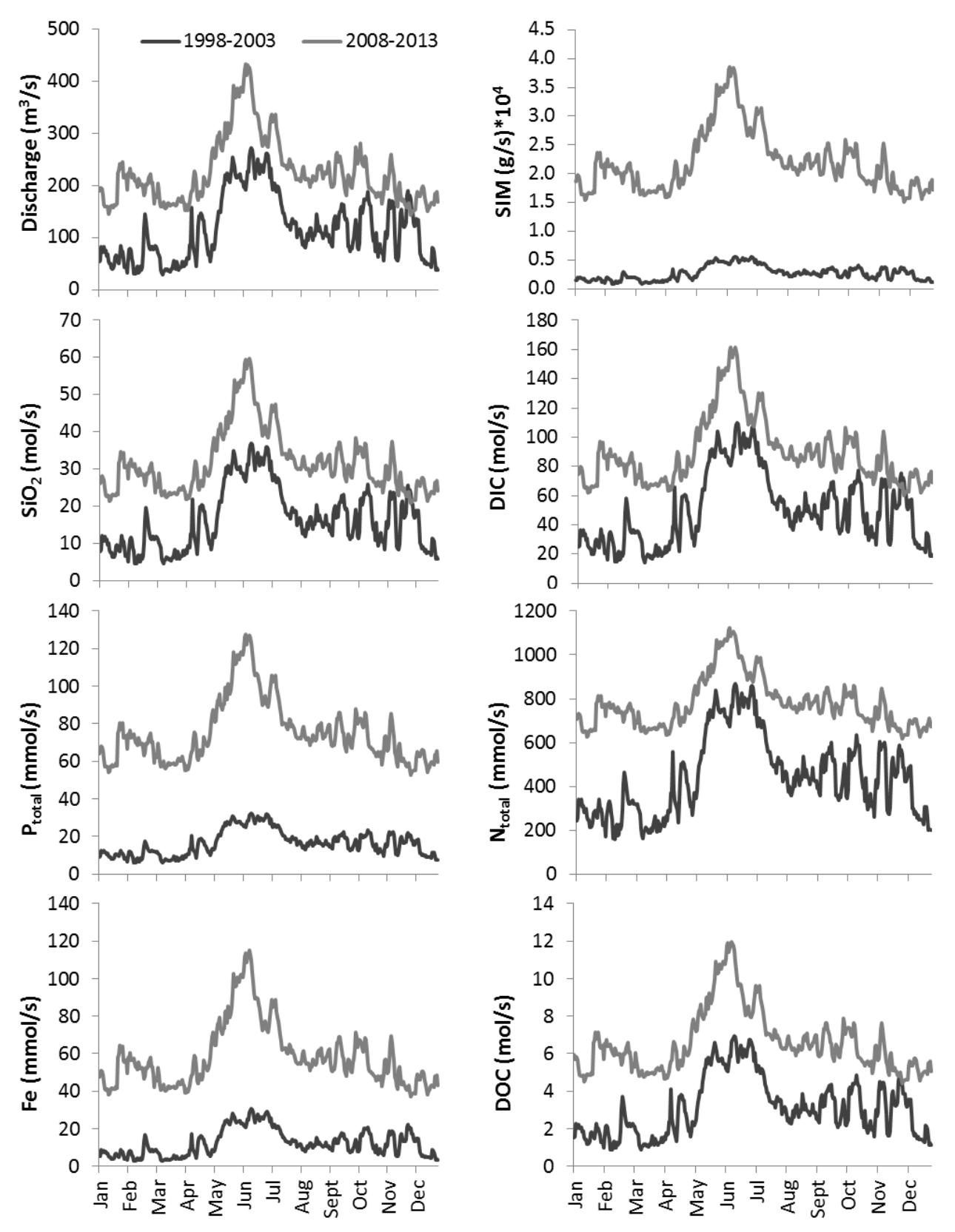


Figure 4. The average daily discharge and suspended- and dissolved flux in the Lagarfljót at Lagarfoss before (dark grey) and after (light grey) damming. The increased discharge in the Lagarfljót after the damming can account for the flux changes of most of the major elements. Phosphorus and Fe fluxes, however, have increased relatively more than discharge, and $\mathrm{N}$ and DOC have increased relatively less than discharge, due to river water concentration changes of these elements. 


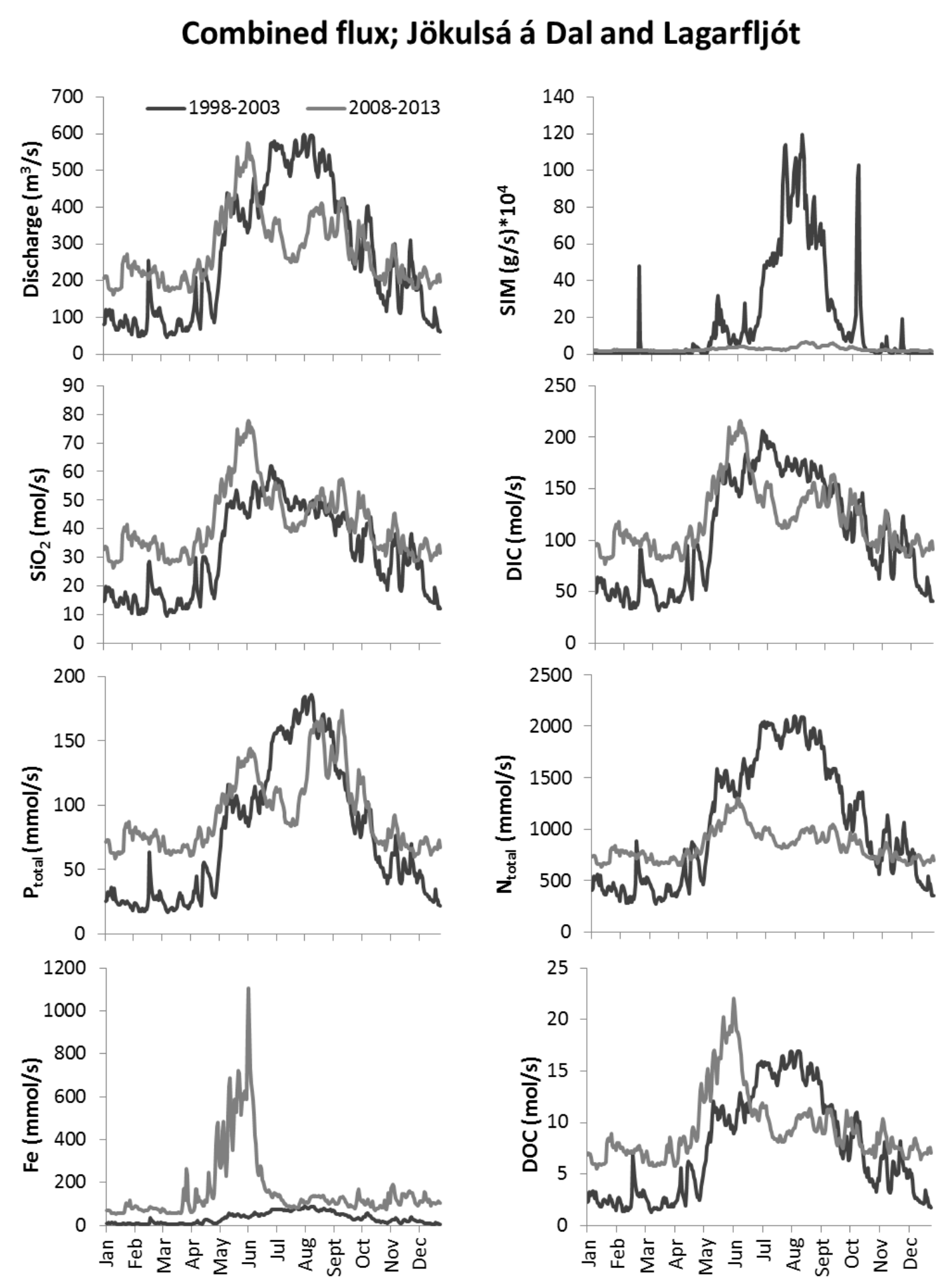

Figure 5. The summed average daily discharge and suspended- and dissolved flux in the Jökulsá á Dal at Hjardarhagi and the Lagarfljót at Lagarfoss before (dark grey) and after damming (light grey). The graphs are were generated from the sum of the data shown in Figs. 3 and 4 and show the overall flux change at the outlet at the coast, which is shared by the rivers. 


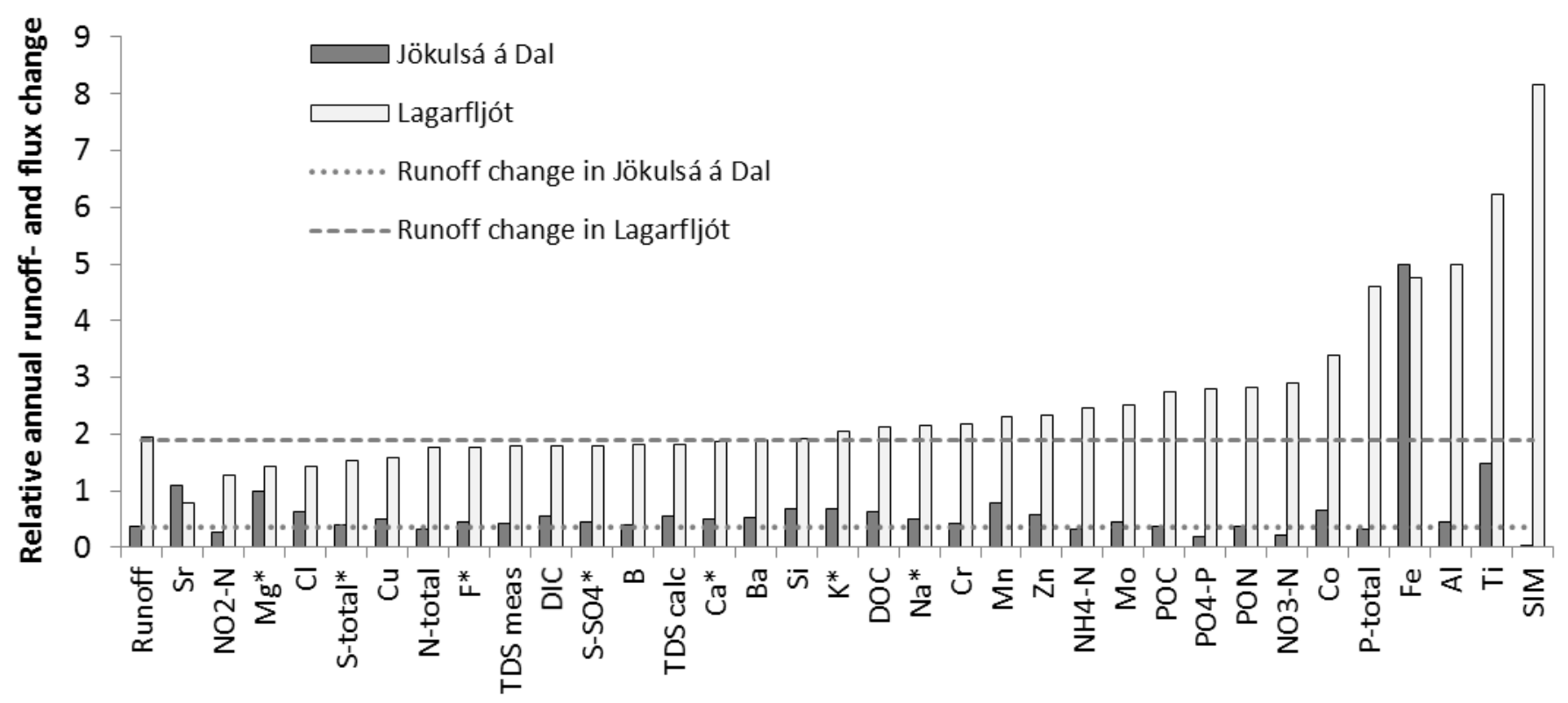

*Elements corrected for atmospheric input. $\mathrm{Cl}$ is $100 \%$ atmospheric TDS was both measured and calculated from the concentration of dissolved major elements

Figure 6. The relative changes of annual runoff, suspended inorganic matter (SIM), and dissolved element fluxes of the Jökulsá á Dal at Hjardarhagi and the Lagarfljót at Lagarfoss. The relative changes were calculated by dividing the annual runoff and fluxes after damming by those before damming. Relative runoff and flux changes which are higher and lower than 1 have increased and decreased, respectively after damming. The upper broken line represents the annual runoff change in the Lagarfljót and the lower dotted line represents the annual runoff change in the Jökulsá á Dal. Riverine fluxes that changed to the same degree as the runoff are controlled by runoff, and the ones that differ from the annual runoff change are influenced by the concentration of riverine constituents - see text. 


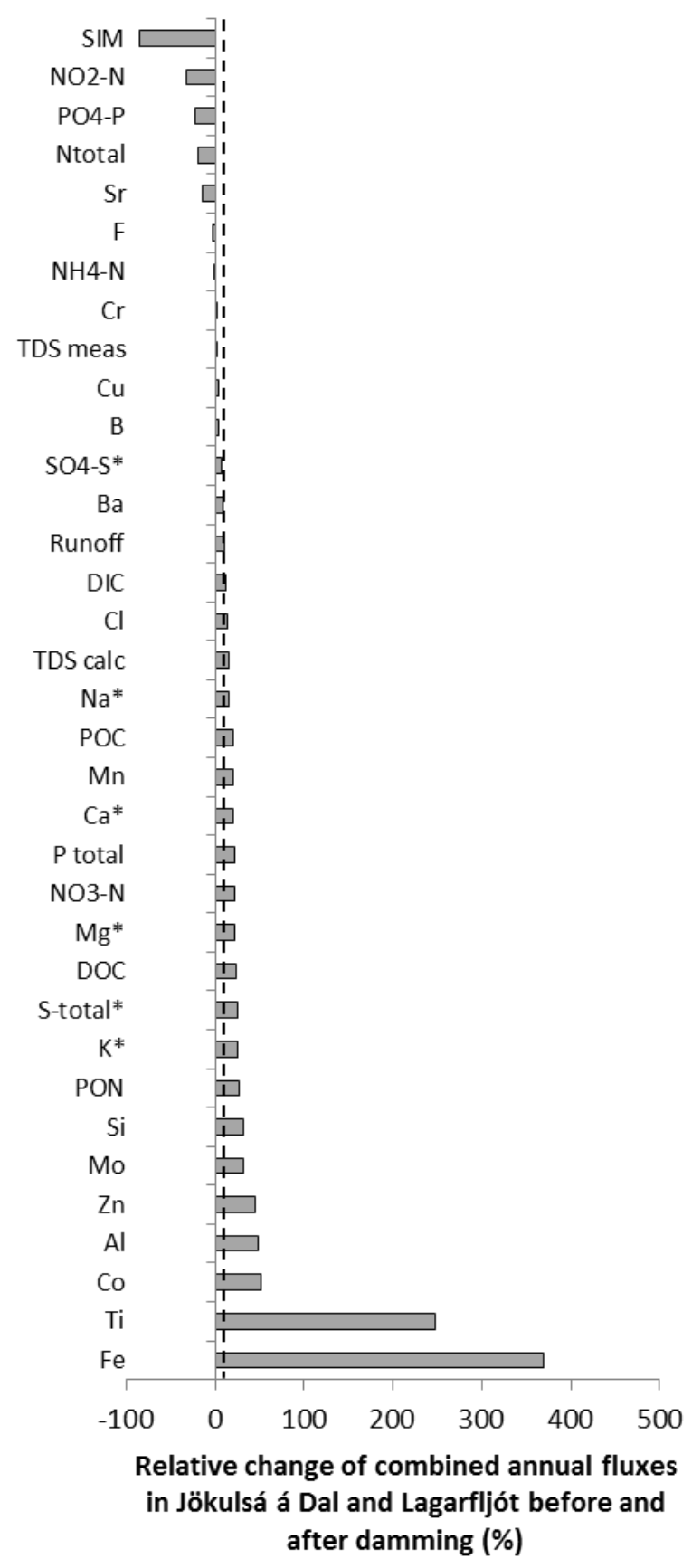

Figure 7. Relative changes in combined elemental flux in the Jökulsá á Dal at Hjardarhagi and the Lagarfljót at Lagarfoss. Negative numbers refer to decreased fluxes due to the damming and positive numbers refer to fluxes that have increased. Runoff increased by $11 \%$ from $1998-$ 2003 to $2008-2013$ as indicated by the broken line. Elements labelled with $*$ have been corrected for atmospheric input. 

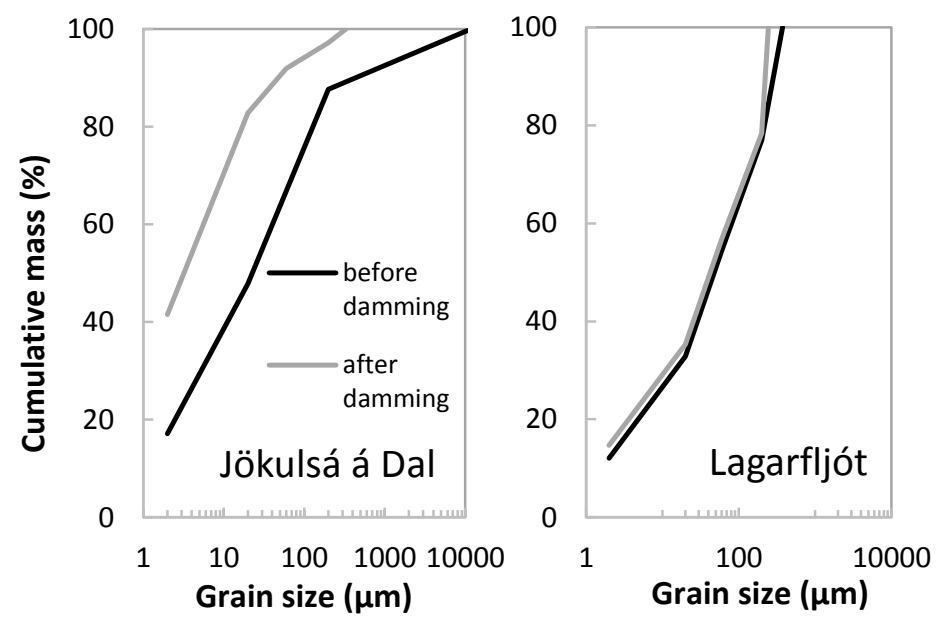

Figure 8. The average particle size distribution of suspended inorganic material in the Jökulsá á Dal and Lagarfljót before and after damming. Results are based on 237 samples from the Jökulsá á Dal and 44 samples from the Lagarfljót collected before damming, and 40 samples from both sampling sites collected after damming. The grain size decreased after damming in the Jökulsá á Dal but is similar in the Lagarfljót after damming. After damming, most of the particulates carried to the estuary are smaller than $60 \mu \mathrm{m}$. 

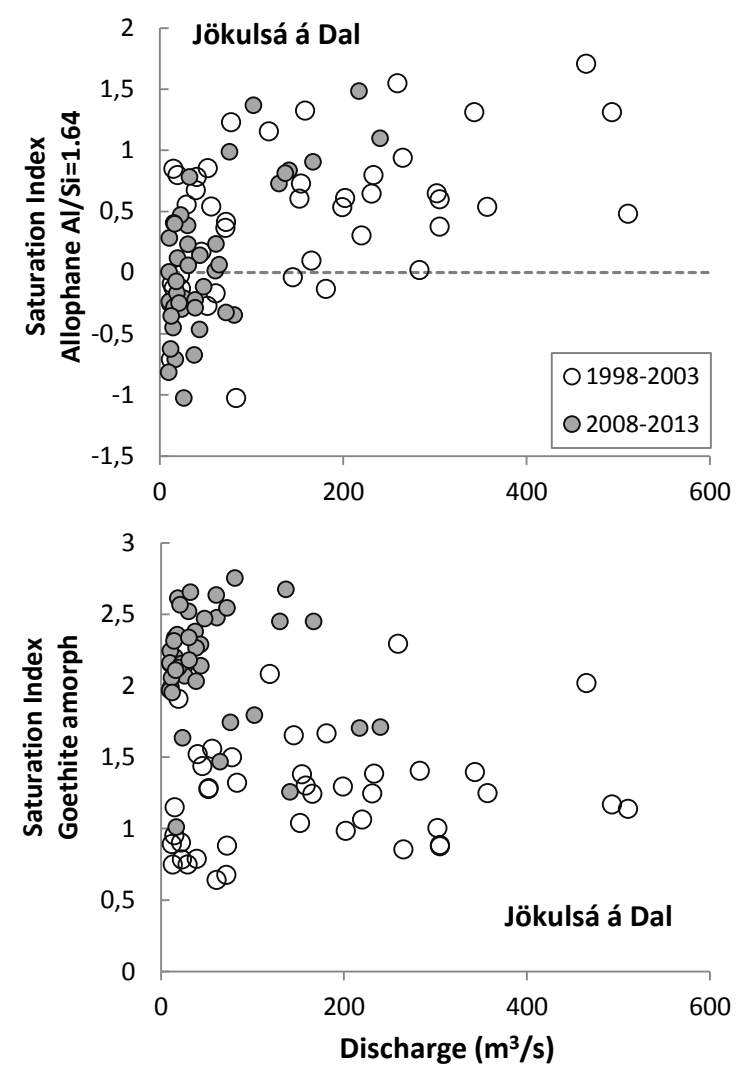

Figure 9. The saturation index of the Jökulsá á Dal water with respect to allophane and amorphous goethite before and after the dam construction. At low discharge, allophane was undersaturated and became supersaturated with increasing discharge. Amorphous goethite was supersaturated before and after damming, but more so after damming. 


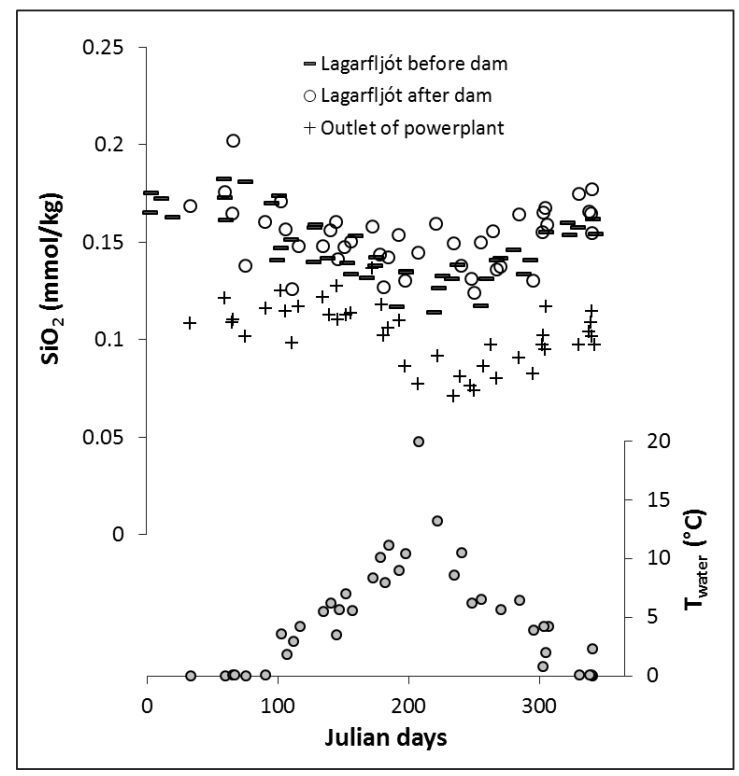

Figure 10. The seasonal concentration of $\mathrm{SiO}_{2}$ in the Lagarfljót before and after damming, and at the outlet of the power plant. Also shown is the water temperature measured at the sampling site in Lagarfljót at the time of sampling during 2008-2013.

\section{Figures in the Electronic Appendix:}

Fig A1a. Daily riverine fluxes of all measured constituents in the Jökulsá á Dal at Hjardarhagi before and after damming. The dark grey lines represent fluxes before damming and the light grey lines represent fluxes after damming.

Fig A1b. Daily riverine fluxes of all measured constituents in the Jökulsá á Dal at Hjardarhagi before and after damming. The dark grey lines represent fluxes before damming and the light grey lines represent fluxes after damming. 
Fig A2a. Daily riverine fluxes of all measured constituents in the Lagarfljót at Lagarfoss before and after damming. The dark grey lines represent fluxes before damming and the light grey lines represent fluxes after damming.

Fig A2b. Daily riverine fluxes of all measured constituents in the Lagarfljót at Lagarfoss before and after damming. The dark grey lines represent fluxes before damming and the light grey lines represent fluxes after damming.

Fig A3a. Combined daily discharge and riverine fluxes of all measured constituents in the Jökulsá á Dal and the Lagarfljót before and after damming. The dark grey lines represent fluxes before damming and the light grey lines represent fluxes after damming.

Fig A3b. Combined daily discharge and riverine fluxes of all measured constituents in the Jökulsá á Dal and the Lagarfljót before and after damming. The dark grey lines represent fluxes before damming and the light grey lines represent fluxes after damming. 


\section{Table captions}

Table 1. Average annual runoff and fluxes of suspended inorganic matter (SIM) and dissolved elements in Jökulsá á Dal and Lagarfljót during 1998-2003 and 2007-2013, before and after damming of Jökulsá á Dal. The rivers merge just before the outlet by the coast and the combined flux is presented in the table. The relative flux change for both rivers and the combined change are presented. A negative number indicates a flux decrease due to the damming and a positive number indicates a flux increase.

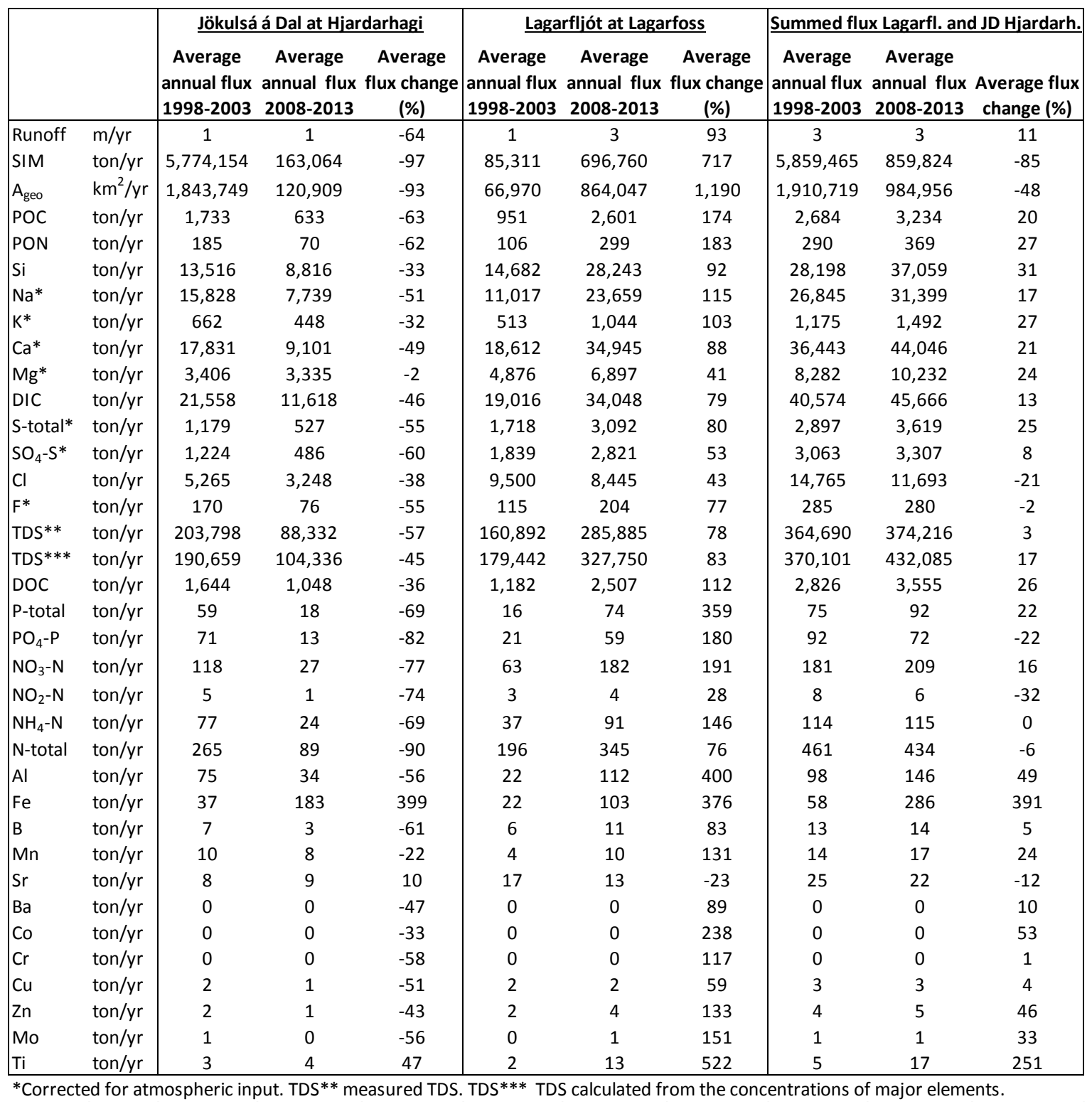




\section{Tables in the Electronic Annex:}

Table A1. Equations describing the variation of element flux (y) as a function of discharge (x) in the Jökulsá á Dal at Hjardarhagi and the Lagarfljót at Lagarfoss before and after dam construction (see Table A2 in the electronic appendix). Overflow of the Hálslón reservoir changes the chemical composition of these elements in Jökulsá á Dal, thus requiring two distinct equations to calculate element fluxes from discharge after the damming of the Jökulsá á Dal. 


\begin{tabular}{|c|c|c|c|c|c|c|c|c|c|c|c|}
\hline \multicolumn{8}{|c|}{ Jökulsá á Dal at Hjardarhagi } & \multicolumn{4}{|c|}{ Lagarfljót at Lagarfoss } \\
\hline \multirow{2}{*}{\begin{tabular}{|l} 
Element \\
$\mathrm{SiO}_{2}$
\end{tabular}} & \multirow{2}{*}{$\begin{array}{l}\text { Unit } \\
\mathrm{mol} / \mathrm{s}\end{array}$} & \multicolumn{2}{|c|}{ 1998-2003 } & \multicolumn{2}{|c|}{ 2008-2013 } & \multicolumn{2}{|c|}{ overflow 2008-2013 } & \multicolumn{2}{|c|}{ 1998-2003 } & \multicolumn{2}{|c|}{ 2008-2013 } \\
\hline & & $y=1.06 x^{0.56}$ & $R^{2}=0.79$ & $y=1.092 x^{0.60}$ & $R^{2}=0.91$ & & & $y=0.193 x^{0.94}$ & $R^{2}=0.98$ & $y=0.165 x^{0.97}$ & $R^{2}=0.96$ \\
\hline $\mathrm{Na*}$ & $\mathrm{mol} / \mathrm{s}$ & $y=1.51 x^{0.57}$ & $R^{2}=0.82$ & $y=1.26 x^{0.57}$ & $R^{2}=0.91$ & & & $y=0.182 x^{0.93}$ & $R^{2}=0.98$ & $y=0.520 x^{0.77}$ & $R^{2}=0.80$ \\
\hline $\mathrm{K}^{*}$ & $\mathrm{~mol} / \mathrm{s}$ & $y=0.030 x^{0.60}$ & $R^{2}=0.73$ & $y=0.017 x^{0.80}$ & $R^{2}=0.82$ & & & $y=0.0052 x^{0.93}$ & $R^{2}=0.93$ & $y=0.0033 x^{1.02}$ & $R^{2}=0.70$ \\
\hline $\mathrm{Ca}^{*}$ & $\mathrm{~mol} / \mathrm{s}$ & $y=0.60 x^{0.65}$ & $R^{2}=0.91$ & $y=0.654 x^{0.64}$ & $R^{2}=0.91$ & & & $y=0.173 x^{0.94}$ & $R^{2}=0.99$ & $y=0.270 x^{0.86}$ & $R^{2}=0.87$ \\
\hline Mg* & $\mathrm{mol} / \mathrm{s}$ & $y=0.81 x^{0.37}$ & $R^{2}=0.37$ & $y=0.386 x^{0.69}$ & $R^{2}=0.88$ & $y=0.177 x^{0.66}$ & $R^{2}=0.68$ & $y=0.079 x^{0.93}$ & $R^{2}=0.97$ & $y=0.0975 x^{0.84}$ & $R^{2}=0.85$ \\
\hline DIC & $\mathrm{mol} / \mathrm{s}$ & $y=3.44 x^{0.59}$ & $R^{2}=0.87$ & $y=3.359 x^{0.59}$ & $R^{2}=0.91$ & & & $y=0.674 x^{0.91}$ & $R^{2}=0.99$ & $y=0.640 x^{0.91}$ & $R^{2}=0.94$ \\
\hline S total* & $\mathrm{mol} / \mathrm{s}$ & $y=0.214 x^{0.37}$ & $R^{2}=0.34$ & $y=0.145 x^{0.28}$ & $R^{2}=0.30$ & $y=0.020 x^{0.86}$ & $R^{2}=0.97$ & $y=0.0275 x^{0.87}$ & $R^{2}=0.97$ & $y=0.0765 x^{0.68}$ & $R^{2}=0.73$ \\
\hline SO4* & $\mathrm{mol} / \mathrm{s}$ & $y=0.184 x^{0.41}$ & $R^{2}=0.48$ & $y=0.073 x^{0.477}$ & $R^{2}=0.58$ & $y=0.0159 x^{0.87}$ & $R^{2}=0.85$ & $y=0.0246 x^{0.91}$ & $R^{2}=0.99$ & $y=0.0321 x^{0.83}$ & $R^{2}=0.85$ \\
\hline $\mathrm{Cl}$ & $\mathrm{mol} / \mathrm{s}$ & $y=0.179 x^{0.68}$ & $R^{2}=0.81$ & $y=0.108 x^{0.84}$ & $R^{2}=0.88$ & $y=0.0393 x^{0.92}$ & $R^{2}=0.87$ & $y=0.0822 x^{0.98}$ & $R^{2}=0.92$ & $y=0.0435 x^{1.04}$ & $R^{2}=0.73$ \\
\hline$F^{*}$ & $\mathrm{mmol} / \mathrm{s}$ & $y=26.2 x^{0.50}$ & $R^{2}=0.74$ & $y=16.2 x^{0.55}$ & $R^{2}=0.88$ & & & $y=2.45 x^{0.92}$ & $R^{2}=0.97$ & $y=5.11 x^{0.78}$ & $R^{2}=0.50$ \\
\hline TDS & $\mathrm{g} / \mathrm{s}$ & $y=163 x^{0.75}$ & $R^{2}=0.88$ & $y=162 x^{0.74}$ & $R^{2}=0.94$ & & & $y=60.0 x^{0.94}$ & $R^{2}=0.97$ & $y=111 x^{0.81}$ & $R^{2}=0.59$ \\
\hline TDS & $\mathrm{g} / \mathrm{s}$ & $y=348 x^{0.60}$ & $R^{2}=0.86$ & $y=354 x^{0.60}$ & $R^{2}=0.92$ & & & $y=73.2 x^{0.92}$ & $R^{2}=0.98$ & $y=82.3 x^{0.89}$ & $R^{2}=0.94$ \\
\hline DOC & $\mathrm{mol} / \mathrm{s}$ & $y=0.026 x^{1.02}$ & $R^{2}=0.83$ & $y=0.079 x^{0.96}$ & $R^{2}=0.75$ & $y=0.0348 x^{0.92}$ & $R^{2}=0.53$ & $y=0.0371 x^{0.94}$ & $R^{2}=0.85$ & $y=0.212 x^{0.70}$ & $R^{2}=0.19$ \\
\hline POC & $\mathrm{mg} / \mathrm{s}$ & $y=84.4 x^{1.26}$ & $R^{2}=0.91$ & $y=173 x^{1.15}$ & $\mathrm{R}^{2}=0.77$ & & & $y=273 x^{0.99}$ & $R^{2}=0.78$ & $y=539 x^{0.93}$ & $R^{2}=0.49$ \\
\hline PON & $\mathrm{mg} / \mathrm{s}$ & $y=7.80 x^{1.28}$ & $R^{2}=0.86$ & $y=12.8 x^{1.24}$ & $R^{2}=0.76$ & & & $y=43.5 x^{0.92}$ & $R^{2}=0.79$ & $y=87.3 x^{0.87}$ & $R^{2}=0.28$ \\
\hline SIM & $\mathrm{g} / \mathrm{s}$ & $y=0.201 x^{2.36}$ & $R^{2}=0.86$ & $y=5.05 x^{1.26}$ & $R^{2}=0.53$ & $y=52.7 x^{1.26}$ & $R^{2}=0.94$ & $y=53.9 x^{0.83}$ & $R^{2}=0.72$ & $y=200 x^{0.87}$ & $R^{2}=0.62$ \\
\hline$P_{\text {total }}$ & $\mathrm{mmol} / \mathrm{s}$ & $y=1.11 x^{0.81}$ & $R^{2}=0.83$ & $y=1.23 x^{0.55}$ & $R^{2}=0.65$ & $y=0.766 x^{0.93}$ & $R^{2}=0.99$ & $y=0.489 x^{0.75}$ & $R^{2}=0.81$ & $y=0.889 x^{0.82}$ & $R^{2}=0.83$ \\
\hline $\mathrm{PO}_{4}$ & $\mathrm{mmol} / \mathrm{s}$ & $y=0.685 x^{0.93}$ & $R^{2}=0.91$ & $y=0.387 x^{0.78}$ & $R^{2}=0.74$ & $y=0.783 x^{0.88}$ & $R^{2}=0.92$ & $y=0.475 x^{0.81}$ & $R^{2}=0.64$ & $y=0.706 x^{0.82}$ & $R^{2}=0.41$ \\
\hline $\mathrm{NO}_{3}$ & $\mathrm{mmol} / \mathrm{s}$ & $y=11.7 x^{0.65}$ & $R^{2}=0.54$ & $y=3.44 x^{0.53}$ & $R^{2}=0.11$ & $y=5.60 x^{0.81}$ & $R^{2}=0.96$ & $y=6.98 x^{0.65}$ & $R^{2}=0.35$ & $y=6.56 x^{0.77}$ & $R^{2}=0.54$ \\
\hline $\mathrm{NO}_{2}$ & $\mathrm{mmol} / \mathrm{s}$ & $y=0.0515 x^{1.06}$ & $R^{2}=0.92$ & $y=0.0406 x^{1.05}$ & $R^{2}=0.88$ & & & $y=0.0832 x^{0.96}$ & $R^{2}=0.81$ & $y=0.0497 x^{0.98}$ & $R^{2}=0.56$ \\
\hline $\mathrm{NH}_{4}$ & $\mathrm{mmol} / \mathrm{s}$ & $y=0.217 x^{1.29}$ & $R^{2}=0.82$ & $y=0.285 x^{1.31}$ & $R^{2}=0.73$ & $y=12 \cdot x^{0.47}$ & $R^{2}=0.14$ & $y=0.259 x^{1.20}$ & $R^{2}=0.76$ & $y=0.277 x^{1.22}$ & $R^{2}=0.24$ \\
\hline$N_{\text {total }}$ & $\mathrm{mmol} / \mathrm{s}$ & $y=12.0 x^{0.79}$ & $R^{2}=0.81$ & $y=0.413 x^{1.19}$ & $R^{2}=0.77$ & & & $y=13.40 x^{0.75}$ & $R^{2}=0.67$ & $y=37.0 x^{0.57}$ & $R^{2}=0.19$ \\
\hline Al & $\mathrm{mmol} / \mathrm{s}$ & $y=0.582 x^{1.00}$ & $R^{2}=0.86$ & $y=1.02 x^{0.82}$ & $R^{2}=0.70$ & $y=0.506 x^{1.14}$ & $R^{2}=0.88$ & $y=0.126 x^{1.11}$ & $R^{2}=0.87$ & $y=0.190 x^{1.20}$ & $R^{2}=0.36$ \\
\hline $\mathrm{Fe}$ & $\mathrm{mmol} / \mathrm{s}$ & $y=0.0374 x^{1.23}$ & $R^{2}=0.70$ & $y=0.239 x^{1.55}$ & $R^{2}=0.77$ & $y=0.247 x^{1.08}$ & $R^{2}=0.58$ & $y=0.063 x^{1.10}$ & $R^{2}=0.76$ & $y=0.214 x^{1.04}$ & $R^{2}=0.13$ \\
\hline B & $\mathrm{mmol} / \mathrm{s}$ & $y=0.617 x^{0.72}$ & $R^{2}=0.77$ & $y=0.776 x^{0.628}$ & $R^{2}=0.81$ & & & $y=0.281 x^{0.88}$ & $R^{2}=0.66$ & $y=0.518 x^{0.76}$ & $R^{2}=0.40$ \\
\hline$M n$ & $\mathrm{mmol} / \mathrm{s}$ & $y=0.0479 x^{0.95}$ & $R^{2}=0.72$ & $y=0.0112 x^{1.51}$ & $R^{2}=0.75$ & $y=0.0583 x^{0.87}$ & $R^{2}=0.90$ & $y=0.10 x^{0.68}$ & $R^{2}=0.41$ & $y=0.186 x^{0.63}$ & $R^{2}=0.24$ \\
\hline $\mathrm{Sr}$ & $\mathrm{mmol} / \mathrm{s}$ & $y=0.390 x^{0.42}$ & $R^{2}=0.49$ & $y=0.197 x^{0.78}$ & $R^{2}=0.92$ & $y=0.192 x^{0.50}$ & $R^{2}=0.74$ & $y=0.0709 x^{0.94}$ & $R^{2}=0.97$ & $y=0.131 x^{0.66}$ & $R^{2}=0.45$ \\
\hline As & $\mu \mathrm{mol} / \mathrm{s}$ & $y=0.750 x^{0.86}$ & $R^{2}=0.76$ & & & & & & & & \\
\hline $\mathrm{Ba}$ & $\mu \mathrm{mol} / \mathrm{s}$ & $y=0.250 x^{0.97}$ & $R^{2}=0.72$ & $y=0.659 x^{0.89}$ & $R^{2}=0.81$ & $y=0.321 x^{0.87}$ & $R^{2}=0.40$ & $y=0.16 x^{1.05}$ & $R^{2}=0.80$ & $y=0.966 x^{0.72}$ & $R^{2}=0.22$ \\
\hline $\mathrm{Cd}$ & $\mu \mathrm{mol} / \mathrm{s}$ & $y=0.0168 x^{1.18}$ & $R^{2}=0.62$ & & & & & & & & \\
\hline Co & $\mu \mathrm{mol} / \mathrm{s}$ & $y=0.361 x^{0.91}$ & $R^{2}=0.74$ & $y=0.446 x^{0.98}$ & $R^{2}=0.85$ & $y=0.627 x^{0.85}$ & $R^{2}=0.49$ & $y=0.248 x^{0.88}$ & $R^{2}=0.71$ & $y=0.560 x^{0.84}$ & $R^{2}=0.31$ \\
\hline $\mathrm{Cr}$ & $\mu \mathrm{mol} / \mathrm{s}$ & $y=16.9 x^{0.51}$ & $R^{2}=0.65$ & $y=12.7 x^{0.493}$ & $R^{2}=0.76$ & & & $y=0.984 x^{0.97}$ & $R^{2}=0.74$ & $y=4.66 x^{0.71}$ & $R^{2}=0.12$ \\
\hline $\mathrm{Cu}$ & $\mu \mathrm{mol} / \mathrm{s}$ & $y=26.0 x^{0.70}$ & $R^{2}=0.68$ & $y=12.1 x^{0.90}$ & $R^{2}=0.93$ & $y=8.30 x^{0.90}$ & $R^{2}=0.84$ & $y=9.03 x^{0.94}$ & $R^{2}=0.94$ & $y=2.07 x^{1.18}$ & $R^{2}=0.76$ \\
\hline $\mathrm{Ni}$ & $\mu \mathrm{mol} / \mathrm{s}$ & $y=4.21 x^{0.99}$ & $R^{2}=0.75$ & $y=1.60 x^{1.10}$ & $R^{2}=0.94$ & $y=1.50 x^{1.01}$ & $R^{2}=0.75$ & $y=1.42 x^{1.21}$ & $R^{2}=0.65$ & $y=0.912 x^{1.12}$ & $R^{2}=0.65$ \\
\hline $\mathrm{Pb}$ & $\mu \mathrm{mol} / \mathrm{s}$ & $y=0.108 x^{0.97}$ & $R^{2}=0.64$ & $y=0.060 x^{1.02}$ & $R^{2}=0.95$ & & & $y=0.035 x^{1.18}$ & $R^{2}=0.79$ & & \\
\hline$Z n$ & $\mu \mathrm{mol} / \mathrm{s}$ & $y=8.640 x^{0.92}$ & $R^{2}=0.56$ & $y=4.16 x^{1.23}$ & $R^{2}=0.76$ & $y=26.9 x^{0.68}$ & $R^{2}=0.79$ & $y=1.93 x^{1.26}$ & $R^{2}=0.61$ & $y=0.471 x^{1.53}$ & $R^{2}=0.40$ \\
\hline $\mathrm{Hg}$ & $\mu \mathrm{mol} / \mathrm{s}$ & & & & & & & & & & \\
\hline Mo & $\mu \mathrm{mol} / \mathrm{s}$ & $y=53.2 x^{0.27}$ & $R^{2}=0.30$ & $y=25.7 x^{0.32}$ & $R^{2}=0.56$ & $y=7.437 x^{0.62}$ & $R^{2}=0.80$ & $y=3.15 x^{0.81}$ & $R^{2}=0.89$ & $y=4.195 x^{0.82}$ & $R^{2}=0.69$ \\
\hline $\mathrm{Ti}$ & $\mu \mathrm{mol} / \mathrm{s}$ & $y=2.12 x^{1.30}$ & $R^{2}=0.76$ & $y=56.0 x^{0.93}$ & $R^{2}=0.61$ & $y=42.0 x^{1.05}$ & $R^{2}=0.54$ & $y=7.12 x^{1.09}$ & $R^{2}=0.70$ & $y=15.4 x^{1.16}$ & $R^{2}=0.15$ \\
\hline $\mathrm{V}$ & $\mathrm{mmol} / \mathrm{s}$ & & & $y=0.958 x^{0.40}$ & $R^{2}=0.65$ & $y=0.333 x^{0.89}$ & $R^{2}=0.96$ & & & $y=0.442 x^{0.72}$ & $R^{2}=0.59$ \\
\hline * correct & $\mathrm{d}$ for atm & ospheric input & & & & & & & & & \\
\hline
\end{tabular}

Table A2. Discharge and concentrations of measured components in rivers monitored from 2007-2013 in Eastern Iceland.

(given in an Excel table)

Table A3. Suspended particulate BET- and geometric surface areas $\left(\mathrm{A}_{\mathrm{geo}}\right)$ in the Jökulsá á Dal at Hjardarhagi and the Lagarfljót at Lagarfoss before (1999-2000) and after (2009-2013) 
damming. The Ageo was calculated from measured grain size distribution and the concentration of suspended inorganic particulates in the samples.

\begin{tabular}{|c|c|c|c|c|c|c|}
\hline $\begin{array}{l}\text { Sample } \\
\text { number }\end{array}$ & Date & Time & $\begin{array}{c}\text { Discharge } \\
\mathrm{m}^{3} / \mathrm{s} \\
\end{array}$ & $\begin{array}{c}\text { BET } \\
\text { Surface area } \\
\mathrm{m}^{2} / \mathrm{g} \\
\end{array}$ & $\begin{array}{c}A_{\text {geo }} \\
\text { Geometric } \\
\text { surface area } \\
\mathrm{m}^{2} / \mathrm{g} \\
\end{array}$ & $\begin{array}{l}\text { Roughness } \\
\text { factor }\end{array}$ \\
\hline \multicolumn{7}{|c|}{ Jökulsá á Dal at Hjardarhagi } \\
\hline 99-A044 & 23/08/1999 & $16: 00$ & 265 & 27 & 0.41 & 66 \\
\hline 99-A051 & 28/09/1999 & $19: 35$ & 152 & 60 & 0.72 & 83 \\
\hline 99-A058 & 03/11/1999 & $14: 30$ & 52 & 59 & 1.24 & 48 \\
\hline 99-A064 & 08/12/1999 & $13: 00$ & 39 & 81 & 1.45 & 56 \\
\hline 00-A026 & $11 / 04 / 2000$ & $18: 20$ & 19 & 11 & 0.54 & 21 \\
\hline 00-A028 & $08 / 05 / 2000$ & $13: 20$ & 283 & 26 & 0.13 & 209 \\
\hline 00-A041 & $07 / 06 / 2000$ & 09:30 & & 54 & 0.41 & 133 \\
\hline 00-A050 & $12 / 07 / 2000$ & $10: 00$ & 302 & 33 & 0.38 & 86 \\
\hline 00-A059 & $09 / 08 / 2000$ & $10: 00$ & 493 & 31 & 0.33 & 95 \\
\hline $10-A 010$ & $14 / 04 / 2010$ & $17: 15$ & 61 & 56 & 0.20 & 284 \\
\hline \multicolumn{7}{|c|}{ Lagarfljót at Lagarfoss } \\
\hline 99-A043 & 23/08/1999 & $12: 10$ & 59 & 11 & 0.38 & 28 \\
\hline 00-A054 & $08 / 08 / 2000$ & $11: 30$ & 53 & 31 & 0.58 & 54 \\
\hline 09A023 & $11 / 08 / 2009$ & $19: 25$ & 363 & 71 & 0.29 & 241 \\
\hline $10 A 025$ & $24 / 08 / 2010$ & $19: 40$ & 263 & 71 & 1.26 & 56 \\
\hline $11 \mathrm{~A} 032$ & $01 / 11 / 2011$ & $12: 25$ & 292 & 68 & 0.57 & 119 \\
\hline $12 \mathrm{~A} 034$ & $05 / 12 / 2012$ & $12: 15$ & 135 & 92 & 0.31 & 297 \\
\hline $13 A 018$ & $18 / 07 / 2013$ & $12: 40$ & 294 & 92 & 0.58 & 159 \\
\hline $13 \mathrm{~A} 022$ & $09 / 09 / 2013$ & $12: 15$ & 180 & 86 & 0.43 & 198 \\
\hline
\end{tabular}

